4

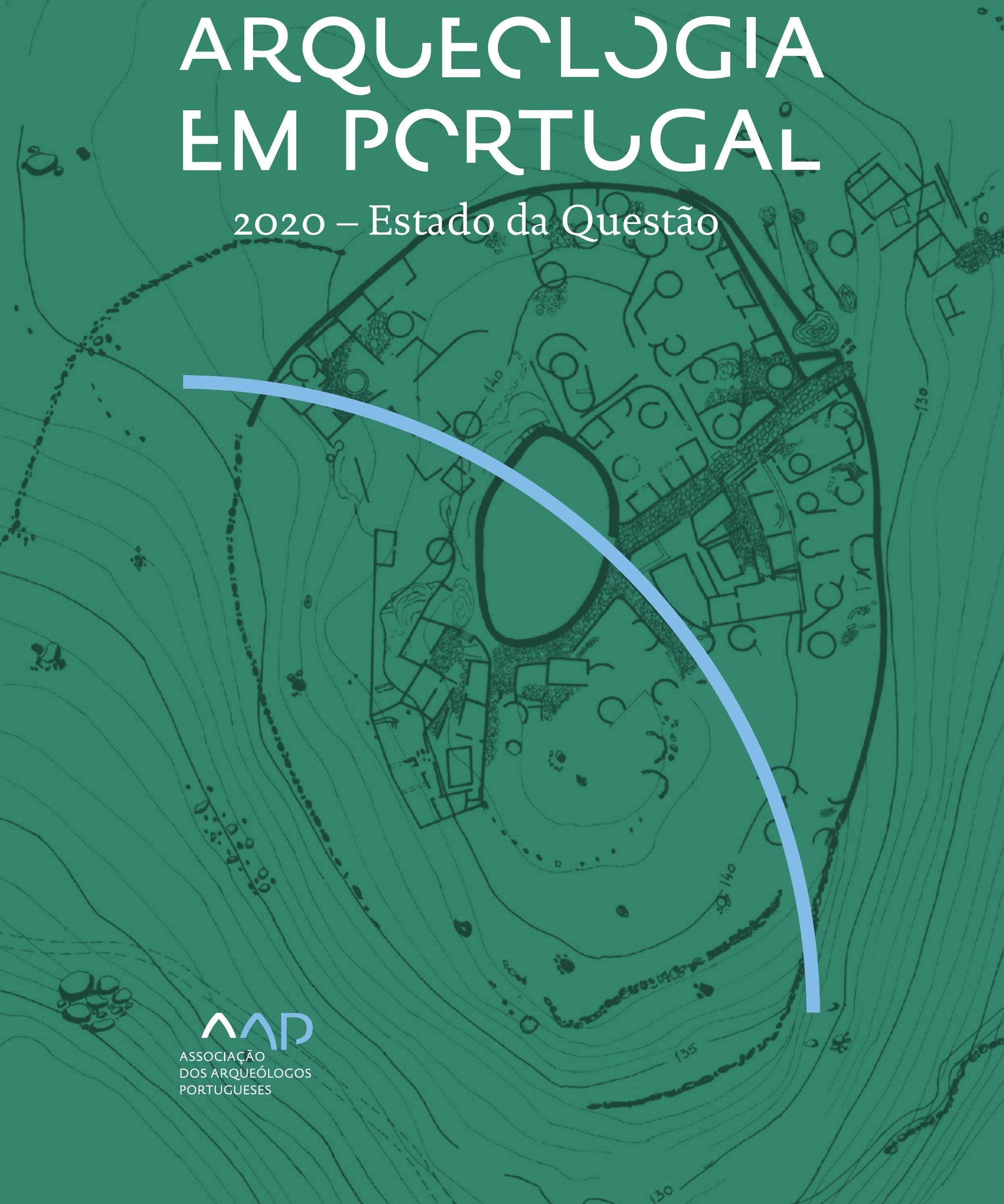


Coordenação editorial: José Morais Arnaud, César Neves e Andrea Martins Design gráfico: Flatland Design

AAP - ISBN: 978-972-9451-89-8

CITCEM - ISBN: 978-989-8970-25-1

Associação dos Arqueólogos Portugueses e CITCEM

Lisboa, 2020

O conteúdo dos artigos é da inteira responsabilidade dos autores. Sendo assim a Associação dos Arqueólogos Portugueses declina qualquer responsabilidade por eventuais equívocos ou questões de ordem ética e legal.

Desenho de capa:

Planta do castro de Monte Mozinho (Museu Municipal de Penafiel).

\section{$\hat{\wedge} \mathrm{P}$}

DOS ARQUEÓLOGOS PORTUGUESES

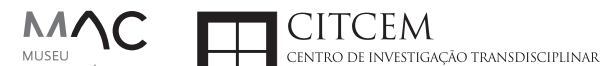
MUSEU
ARQUELLÓGICO
DO CARMO
U.PORTO

FLUP FACULDADE DE LETRAS
UNIVERSIDADE DO PORTO

Apoio

EC para a Ciência 


\section{Índice}

15 Prefácio

José Morais Arnaud

\section{Historiografia e Teoria}

17 Território, comunidade, memória e emoção: a contribuição da história da arqueologia (algumas primeiras e breves reflexões)

Ana Cristina Martins

25 Como descolonizar a arqueologia portuguesa?

Rui Gomes Coelho

41 Arqueologia e Modernidade: uma revisitação pessoal e breve de alguns aspetos da obra homónima de Julian Thomas de 2004

Vítor Oliveira Jorge

57 Dados para a História das Mulheres na Arqueologia portuguesa, dos finais do século XIX aos inícios do século XX: números, nomes e tabelas

Filipa Dimas / Mariana Diniz

73 Retractos da arqueologia portuguesa na imprensa: (in)visibilidades no feminino

Catarina Costeira / Elsa Luís

85 Arqueologia e Arqueólogos no Norte de Portugal Jacinta Bugalhão

101 Vieira Guimarães (1864-1939) e a arqueologia em Tomar: uma abordagem sobre o território e as gentes

João Amendoeira Peixoto / Ana Cristina Martins

115 Os memoráveis? A arqueologia algarvia na imprensa nacional e regional na presente centúria (2001-2019): características, visões do(s) passado(s) e a arqueologia

enquanto marca

Frederico Agosto / João Silva

129 A Evolução da Arqueologia Urbana e a Valorização Patrimonial no Barlavento Algarvio: Os casos de Portimão e Silves

Artur Mateus / Diogo Varandas / Rafael Boavida

\section{Gestão, Valorização e Salvaguarda do Património}

145 O Caderno Reivindicativo e as condições de trabalho em Arqueologia Miguel Rocha / Liliana Matias Carvalho / Regis Barbosa / Mauro Correia / Sara Simões / Jacinta Bugalhão / Sara Brito / Liliana Veríssimo Carvalho / Richard Peace / Pedro Peça / Cézer Santos

155 Os Estudos de Impacte Patrimonial como elemento para uma estratégia sustentável de minimização de impactes no âmbito de reconversões agrícolas Tiago do Pereiro

165 Salvaguarda de Património arqueológico em operações florestais: gestão e sensibilização Filipa Bragança / Gertrudes Zambujo / Sandra Lourenço / Belém Paiva / Carlos Banha / Frederico Tatá Regala / Helena Moura / Jacinta Bugalhão / João Marques / José Correia / Pedro Faria / Samuel Melro

179 Os valores do Património: uma investigação sobre os Sítios Pré-históricos de Arte Rupestre do Vale do Rio Côa e de Siega Verde José Paulo Francisco 
189 Conjugando recursos arqueológicos e naturais para potenciar as visitas ao Geoparque Litoral de Viana do Castelo (Noroeste de Portugal)

Hugo A. Sampaio / Ana M.S. Bettencourt / Susana Marinho / Ricardo Carvalhido

203 Áreas de Potencial Arqueológico na Região do Médio Tejo: Modelo Espacial Preditivo Rita Ferreira Anastácio / Ana Filipa Martins / Luiz Oosterbeek

223 Património Arqueológico e Gestão Territorial: O contributo da Arqueologia para a revisão do PDM de Avis

Ana Cristina Ribeiro

237 A coleção arqueológica do extinto Museu Municipal do Porto - Origens, Percursos e Estudos

Sónia Couto

251 Valpaços - uma nova carta arqueológica

Pedro Pereira / Maria de Fátima Casares Machado

263 Arqueologia na Cidade de Peniche

Adriano Constantino / Luís Rendeiro

273 Arqueologia Urbana: a cidade de Lagos como caso de Estudo Cátia Neto

285 Estratégias de promoção do património cultural subaquático nos Açores. O caso da ilha do Faial

José Luís Neto / José Bettencourt / Luís Borges / Pedro Parreira

297 Carta Arqueológica da Cidade Velha: Uma primeira abordagem

Jaylson Monteiro / Nireide Tavares / Sara da Veiga / Claudino Ramos / Edson Brito /

Carlos Carvalho / Francisco Moreira / Adalberto Tavares

311 Antropologia Virtual: novas metodologias para a análise morfológica e funcional Ricardo Miguel Godinho / Célia Gonçalves

\section{Didáctica da Arqueologia}

327 Como os projetos de Arqueologia podem contribuir para uma comunidade culturalmente mais consciente Alexandra Figueiredo / Claúdio Monteiro / Adolfo Silveira / Ricardo Lopes

337 Educação Patrimonial - Um cidadão esclarecido é um cidadão ativo! Ana Paula Almeida

351 A aproximação da Arqueologia à sala de aula: um caso de estudo no $3^{\circ}$ ciclo do Ensino Básico Luís Serrão Gil

363 Arqueologia 3.o - Pensar e comunicar a Arqueologia para um futuro sustentável Mónica Rolo

377 “Conversa de Arqueólogos" - Divulgar a Arqueologia em tempos de Pandemia Diogo Teixeira Dias

389 Escola Profissional de Arqueologia: desafios e oportunidades Susana Nunes / Dulcineia Pinto / Júlia Silva / Ana Mascarenhas

399 Os Museus de Arqueologia e os Jovens: a oferta educativa para o público adolescente Beatriz Correia Barata / Leonor Medeiros

411 O museu universitário como mediador entre a ciência e a sociedade: o exemplo da secção de arqueologia no Museu de História Natural e da Ciência da Universidade do Porto (MHNC-UP)

Rita Gaspar 
421 Museu de Lanifícios: Real Fábrica de Panos. Atividades no âmbito da Arqueologia Beatriz Correia Barata / Rita Salvado

427 Arqueologia Pública e o caso da localidade da Mata (Torres Novas) Cláudia Manso / Ana Rita Ferreira / Cristiana Ferreira / Vanessa Cardoso Antunes

431 Do sítio arqueológico ao museu: um percurso (também) didático Lídia Fernandes

447 Estão todos convidados para a Festa! E para dançar também... O projecto do Serviço Educativo do Museu Arqueológico do Carmo na $5^{\underline{a}}$ Edição da Festa da Arqueologia Rita Pires dos Santos

459 O “Clã de Carenque”, um projeto didático de arqueologia Eduardo Gonzalez Rocha

469 Mediação cultural: peixe que puxa carroça nas Ruínas Romanas de Troia Inês Vaz Pinto / Ana Patrícia Magalhães / Patrícia Brum / Filipa Santos

481 Didática Arqueológica, experiências do Projeto Mértola Vila Museu Maria de Fátima Palma / Clara Rodrigues / Susana Gómez / Lígia Rafael

\section{Arte Rupestre}

497 Os inventários de arte rupestre em Portugal Mila Simões de Abreu

513 O projeto FIRST-ART - conservação, documentação e gestão das primeiras manifestações de arte rupestre no Sudoeste da Península Ibérica: as grutas do Escoural e Maltravieso Sara Garcês / Hipólito Collado / José Julio García Arranz / Luiz Oosterbeek / António Carlos Silva / Pierluigi Rosina / Hugo Gomes / Anabela Borralheiro Pereira / George Nash / Esmeralda Gomes / Nelson Almeida / Carlos Carpetudo

523 Trabalhos de documentação de arte paleolítica realizados no âmbito do projeto PalæoCôa André Tomás Santos / António Fernando Barbosa / Luís Luís / Marcelo Silvestre / Thierry Aubry

537 Imagens fantasmagóricas, silhuetas elusivas: as figuras humanas na arte do Paleolítico Superior da região do Côa Mário Reis

$55^{1}$ Os motivos zoomórficos representados nas placas de tear de Vila Nova de São Pedro (Azambuja, Portugal) Andrea Martins / César Neves / José M. Arnaud / Mariana Diniz

571 Arte Rupestre do Monte de Góios (Lanhelas, Caminha). Síntese dos resultados dos trabalhos efectuados em 2007-2009 Mário Varela Gomes

599 Gravuras rupestres de barquiformes no Monte de S. Romão, Guimarães, Noroeste de Portugal Daniela Cardoso

613 Círculos segmentados gravados na Bacia do Rio Lima (Noroeste de Portugal): contributos para o seu estudo Diogo Marinho / Ana M.S. Bettencourt / Hugo Aluai Sampaio

631 Equídeos gravados no curso inferior do Rio Mouro, Monção (NW Portugal). Análise preliminar Coutinho, L.M. / Bettencourt, A.M.S / Sampaio, Hugo A.S

645 Paletas na Arte Rupestre do Noroeste de Portugal. Inventário preliminar Bruna Sousa Afonso / Ana M. S. Bettencourt / Hugo A. Sampaio 


\section{Pré-História}

661 O projeto Miño/Minho: balanço de quatro anos de trabalhos arqueológicos Sérgio Monteiro-Rodrigues / João Pedro Cunha-Ribeiro / Eduardo Méndez-Quintas / Carlos Ferreira / Pedro Xavier / José Meireles / Alberto Gomes / Manuel Santonja / Alfredo Pérez-González

677 A ocupação paleolítica da margem esquerda do Baixo Minho: a indústria lítica do sítio de Pedreiras 2 (Monção, Portugal) e a sua integração no contexto regional Carlos Ferreira / João Pedro Cunha-Ribeiro / Sérgio Monteiro-Rodrigues / Eduardo Méndez-Quintas / Pedro Xavier / José Meireles / Alberto Gomes / Manuel Santonja / Alfredo Pérez-González

693 O sítio acheulense do Plistocénico médio da Gruta da Aroeira Joan Daura / Montserrat Sanz / Filipa Rodrigues / Pedro Souto / João Zilhão

703 As sociedades neandertais no Barlavento algarvio: modelos preditivos com recurso aos SIG

Daniela Maio

715 A utilização de quartzo durante o Paleolítico Superior no território dos vales dos rios Vouga e Côa

Cristina Gameiro / Thierry Aubry / Bárbara Costa / Sérgio Gomes / Luís Luís / Carmen Manzano / André Tomás Santos

733 Uma perspetiva diacrónica da ocupação do concheiro do Cabeço da Amoreira (Muge, Portugal) a partir da tecnologia lítica Joana Belmiro / João Cascalheira / Célia Gonçalves

745 Novos dados sobre a Pré-história Antiga no concelho de Palmela. A intervenção arqueológica no sítio do Poceirão I

Michelle Teixeira Santos

757 Problemas em torno de Datas Absolutas Pré-Históricas no Norte do Alentejo Jorge de Oliveira

771 Povoamento pré-histórico nas áreas montanhosas do NO de Portugal: o Abrigo 1 de Vale de Cerdeira Pedro Xavier / José Meireles / Carlos Alves

783 Apreciação do povoamento do Neolítico Inicial na Baixa Bacia do Douro. A Lavra I (Serra da Aboboreira) como caso de estudo Maria de Jesus Sanches

797 O Processo de Neolitização na Plataforma do Mondego: os dados do Sector C do Outeiro dos Castelos de Beijós (Carregal do Sal)

João Carlos de Senna-Martinez / José Manuel Quintã Ventura / Andreia Carvalho / Cíntia Maurício

823 Novos trabalhos na Lapa da Bugalheira (Almonda, Torres Novas) Filipa Rodrigues / Pedro Souto / Artur Ferreira / Alexandre Varanda / Luís Gomes / Helena Gomes / João Zilhão

837 A pedra polida e afeiçoada do sítio do Neolítico médio da Moita do Ourives (Benavente, Portugal)

César Neves

857 Casal do Outeiro (Encarnação, Mafra): novos contributos para o conhecimento do povoamento do Neolítico final na Península de Lisboa.

Cátia Delicado / Carlos Maneira e Costa / Marta Miranda / Ana Catarina Sousa

873 Stresse infantil, morbilidade e mortalidade no sítio arqueológico do Neolítico Final/ Calcolítico ( $4^{\circ}$ e $3^{\circ}$ milénio a.C.) do Monte do Carrascal 2 (Ferreira do Alentejo, Beja) Liliana Matias de Carvalho / Sofia N. Wasterlain 
885 Come together: O Conjunto Megalítico das Motas (Monção, Viana do Castelo) e as expressões Campaniformes do Alto Minho Ana Catarina Basílio / Rui Ramos

899 Trabalhos arqueológicos no sítio Calcolítico da Pedreira do Poio Carla Magalhães / João Muralha / Mário Reis / António Batarda Fernandes

913 O sítio arqueológico de Castanheiro do Vento. Da arquitectura do sítio à arquitectura de um território João Muralha Cardoso

925 Estudo zooarqueológico das faunas do Calcolítico final de Vila Nova de São Pedro (Azambuja, Portugal): Campanhas de 2017 e 2018 Cleia Detry / Ana Catarina Francisco / Mariana Diniz / Andrea Martins / César Neves / José Morais Arnaud

943 As faunas depositadas no Museu Arqueológico do Carmo provenientes de Vila Nova de São Pedro (Azambuja): as campanhas de 1937 a 1967 Ana Catarina Francisco / Cleia Detry / César Neves / Andrea Martins / Mariana Diniz / José Morais Arnaud

959 Análise funcional de material lítico em sílex do castro de Vila Nova de S. Pedro (Azambuja, Portugal): uma primeira abordagem Rafael Lima

971 O recinto da Folha do Ouro 1 (Serpa) no contexto dos recintos de fossos calcolíticos alentejanos

António Carlos Valera / Tiago do Pereiro / Pedro Valério / António M. Monge Soares

\section{Proto-História}

987 Produção de sal marinho na Idade do Bronze do noroeste Português. Alguns dados para uma reflexão

Ana M. S. Bettencourt / Sara Luz / Nuno Oliveira / Pedro P. Simões / Maria Isabel C. Alves / Emílio Abad-Vidal

1001 A estátua-menir do Pedrão ou de São Bartolomeu do Mar (Esposende, noroeste de Portugal) no contexto arqueológico da fachada costeira de entre os rios Neiva e Cávado Ana M. S. Bettencourt / Manuel Santos-Estévez / Pedro Pimenta Simões / Luís Gonçalves

1015 O Castro do Muro (Vandoma/Baltar, Paredes) - notas para uma biografia de ocupação da Idade do Bronze à Idade Média

Maria Antónia D. Silva / Ana M. S. Bettencourt / António Manuel S. P. Silva / Natália Félix

1031 Do Bronze Final à Idade Média - continuidades e hiatos na ocupação de Povoados em Oliveira de Azeméis João Tiago Tavares / Adriaan de Man

1041 As faunas do final da Idade do Bronze no Sul de Portugal: leituras desde o Outeiro do Circo (Beja)

Nelson J. Almeida / Íris Dias / Cleia Detry / Eduardo Porfírio / Miguel Serra

1055 A Espada do Monte das Oliveiras (Serpa) - uma arma do Bronze Pleno do Sudoeste Rui M. G. Monge Soares / Pedro Valério / Mariana Nabais / António M. Monge Soares

1065 São Julião da Branca (Albergaria-a-Velha) - Investigação e valorização de um povoado do Bronze Final

António Manuel S. P. Silva / Paulo A. P. Lemos / Sara Almeida e Silva / Edite Martins de Sá

1083 Do castro de S. João ao Mosteiro de Santa Clara: notícia de uma intervenção arqueológica, em Vila do Conde Rui Pinheiro 
1095 O castro de Ovil (Espinho), um quarto de século de investigação - resultados e questões em aberto

Jorge Fernando Salvador / António Manuel S. P. Silva

1111 O Castro de Salreu (Estarreja), um povoado proto-histórico no litoral do Entre Douro e Vouga

Sara Almeida e Silva / António Manuel S. P. Silva / Paulo A. P. Lemos / Edite Martins de Sá

1127 Castro de Nossa Senhora das Necessidades (Sernancelhe): uma primeira análise artefactual Telma Susana O. Ribeiro

${ }_{1141}$ A cividade de Bagunte. O estado atual da investigação Pedro Brochado de Almeida

1153 Zoomorfos na cerâmica da Idade do Ferro no NW Peninsular: inventário, cronologias e significado Nuno Oliveira / Cristina Seoane

1163 Vasos gregos em Portugal: diferentes maneiras de contar a história do intercâmbio cultural na Idade do Ferro

Daniela Ferreira

1175 Os exotica da necrópole da Idade do Ferro do Olival do Senhor dos Mártires (Alcácer do Sal) no seu contexto regional

Francisco B. Gomes

\section{Antiguidade Clássica e Tardia}

1191 O uso de madeira como combustível no sítio da Quinta de Crestelos (Baixo Sabor): da Idade do Ferro à Romanização Filipe Vaz / João Tereso / Sérgio Simões Pereira / José Sastre / Javier Larrazabal Galarza / Susana Cosme / José António Pereira / Israel Espi

1207 Cultivos de Época Romana no Baixo Sabor: continuidade em tempos de mudança? João Pedro Tereso / Sérgio Simões Pereira / Filipe Santos / Luís Seabra / Filipe Vaz

1221 A casa romana na Hispânia: aplicação dos modelos itálicos nas províncias ibéricas Fernanda Magalhães / Diego Machado / Manuela Martins

1235 As pinturas murais romanas da Rua General Sousa Machado, n. ${ }^{5}$ 1, Chaves José Carvalho

1243 Trás do Castelo (Vale de Mir, Pegarinhos, Alijó) - Uma exploração agrícola romana do Douro

Tony Silvino / Pedro Pereira

1255 A sequência de ocupação no quadrante sudeste de Bracara Augusta: as transformações de uma unidade doméstica Lara Fernandes / Manuela Martins

1263 Os Mosaicos com decoração geométrica e geométrico-vegetalista dos sítios arqueológicos da área do Conuentus Bracaraugustanus. Novas abordagens quanto à conservação, restauro, decoração e datação Maria de Fátima Abraços / Licínia Wrench

1277 “Casa Romana” do Castro de São Domingos (Cristelos, Lousada): Escavação, Estudo e Musealização Paulo André de P. Lemos

1291 A arqueobotânica no Castro de Guifões (Matosinhos, Noroeste de Portugal): O primeiro estudo carpológico

Luís Seabra / Andreia Arezes / Catarina Magalhães / José Varela / João Pedro Tereso 
1305 Um Horreum Augustano na Foz do Douro (Monte do Castelo de Gaia, Vila Nova de Gaia) Rui Ramos

1311 Ponderais romanos na Lusitânia: padrões, formas, materiais e contextos de utilização Diego Barrios Rodríguez

1323 Um almofariz centro-itálico na foz do Mondego

Marco Penajoia

1335 Estruturas romanas de Carnide - Lisboa Luísa Batalha / Mário Monteiro / Guilherme Cardoso

1347 O contexto funerário do sector da "necrópole NO" da Rua das Portas de S. Antão (Lisboa): o espaço, os artefactos, os indivíduos e a sua interconectividade na interpretação do passado Sílvia Loja, José Carlos Quaresma, Nelson Cabaço, Marina Lourenço, Sílvia Casimiro, Rodrigo Banha da Silva, Francisca Alves-Cardoso

${ }_{1361}$ Povoamento em época Romana na Amadora - resultados de um projeto pluridisciplinar Gisela Encarnação / Vanessa Dias

1371 A Arquitectura Residencial em Mirobriga (Santiago do Cacém): contributo a partir de um estudo de caso Filipe Sousa / Catarina Felício

${ }_{1385}$ O fim do ciclo. Saneamento e gestão de resíduos nos edifícios termais de Mirobriga (Santiago do Cacém)

Catarina Felício / Filipe Sousa

1399 Balsa, Topografia e Urbanismo de uma Cidade Portuária Vítor Silva Dias / João Pedro Bernardes / Celso Candeias / Cristina Tété Garcia

1413 No Largo das Mouras Velhas em Faro (2017): novas evidências da necrópole norte de Ossonoba e da sua ocupação medieval Ricardo Costeira da Silva / Paulo Botelho / Fernando Santos / Liliana Nunes

1429 Instrumentos de pesca recuperados numa fábrica de salga em Ossonoba (Faro) Inês Rasteiro / Ricardo Costeira da Silva / Paulo Botelho

1439 A Necrópole Romana do Eirô, Duas Igrejas (Penafiel): intervenção arqueológica de 2016 Laura Sousa / Teresa Soeiro

1457 Ritual, descarte ou afetividade? A presença de Canis lupus familiaris na Necrópole Noroeste de Olisipo (Lisboa)

Beatriz Calapez Santos / Sofia Simões Pereira / Rodrigo Banha da Silva / Sílvia Casimiro / Cleia Detry / Francisca Alves Cardoso

1467 Dinâmicas económicas em Bracara na Antiguidade Tardia Diego Machado / Manuela Martins / Fernanda Magalhães / Natália Botica

1479 Cerâmicas e Vidros da Antiguidade Tardia do Edifício sob a Igreja do Bom Jesus (Vila Nova de Gaia) Joaquim Filipe Ramos

1493 Novos contributos para a topografia histórica de Mértola no período romano e na Antiguidade Tardia Virgílio Lopes

\section{8. Época Medieval}

1511 Cerâmicas islâmicas no Garb setentrional "português": algumas evidências e incógnitas Constança dos Santos / Helena Catarino / Susana Gómez / Maria José Gonçalves / Isabel Inácio / Gonçalo Lopes / Jacinta Bugalhão / Sandra Cavaco / Jaquelina Covaneiro / Isabel Cristina Fernandes / Ana Sofia Gomes 
1525 Contributo para o conhecimento da cosmética islâmica, em Silves, durante a Idade Média Rosa Varela Gomes

1537 Yábura e o seu território - uma análise histórico-arqueológica de Évora entre os séculos VIII-XII José Rui Santos

1547 A encosta sul do Castelo de Palmela - resultados preliminares da escavação arqueológica Luís Filipe Pereira / Michelle Teixeira Santos

1559 A igreja de São Lourenço (Mouraria, Lisboa): um conjunto de silos e de cerâmica medieval islâmica

Andreia Filipa Moreira Rodrigues

1571 O registo material de movimentações populacionais no Médio Tejo, durante os séculos XII-XIII. Dois casos de "sunken featured buildings", nos concelhos de Cartaxo e Torres Novas Marco Liberato / Helena Santos / Nuno Santos

1585 O nordeste transmontano nos alvores da Idade média. Notas para reflexão Ana Maria da Costa Oliveira

1601 Sepulturas escavadas na rocha do Norte de Portugal e do Vale do Douro: primeiros resultados do Projecto SER-NPVD

Mário Jorge Barroca / César Guedes / Andreia Arezes / Ana Maria Oliveira

1619 "Portucalem Castrum Novum" entre o Mediterrâneo e o Atlântico: o estudo dos materiais cerâmicos alto-medievais do arqueossítio da rua de D. Hugo, nํ. 5 (Porto) João Luís Veloso

1627 A Alta Idade Média na fronteira de Lafões: notas preliminares sobre a Arqueologia no Concelho de Vouzela

Manuel Luís Real / Catarina Tente

1641 Um conjunto cerâmico medieval fora de portas: um breve testemunho aveirense Susana Temudo

${ }_{1651}$ Os Lóios do Porto: uma perspetiva integrada no panorama funerário da Baixa Idade Média à Época Moderna em meios urbanos em Portugal

Ana Lema Seabra

1659 O Caminho Português Interior de Santiago como eixo viário na Idade Média Pedro Azevedo

1665 Morfologia Urbana: Um exercício em torno do Castelo de Ourém André Donas-Botto / Jaqueline Pereira

1677 Intervenção arqueológica na Rua Marquês de Pombal/Largo do Espírito Santo (Bucelas, Loures)

Florbela Estêvão / Nathalie Antunes-Ferreira / Dário Ramos Neves / Inês Lisboa

1691 O Cemitério Medieval do Poço do Borratém e a espacialidade funerária na cidade de Lisboa Inês Belém / Vanessa Filipe / Vasco Noronha Vieira / Sónia Ferro / Rodrigo Banha da Silva

1705 Um Espaço Funerário Conventual do séc. XV em Lisboa: o caso do Convento de São Domingos da Cidade Sérgio Pedroso / Sílvia Casimiro / Rodrigo Banha da Silva / Francisca Alves Cardoso

\section{9. Época Moderna e Contemporânea}

1721 Arqueologia Moderna em Portugal: algumas reflexões críticas em torno da quantificação de conjuntos cerâmicos e suas inferências históricas e antropológicas Rodrigo Banha da Silva / André Bargão / Sara da Cruz Ferreira

1733 Faianças de dois contextos entre os finais do século XVI e XVIII do Palácio dos Condes de Penafiel, Lisboa

Martim Lopes / Tomás Mesquita 
1747 Um perfil de consumo do século XVIII na foz do Tejo: O caso do Mercado da Ribeira, Lisboa Sara da Cruz Ferreira / Rodrigo Banha da Silva / André Bargão

1761 Os Cachimbos dos Séculos XVII e XVIII do Palácio Mesquitela e Convento dos Inglesinhos (Lisboa)

Inês Simão / Marina Pinto / João Pimenta / Sara da Cruz Ferreira / André Bargão / Rodrigo Banha da Silva

1775 "Tomar os fumos da erua que chamão em Portugal erua sancta». Estudo de Cachimbos provenientes da Rua do Terreiro do Trigo, Lisboa

Miguel Martins de Sousa / José Pedro Henriques / Vanessa Galiza Filipe

1787 Cachimbos de Barro Caulínitico da Sé da Cidade Velha (República de Cabo Verde)

Rodrigo Banha da Silva / João Pimenta / Clementino Amaro

1801 Algumas considerações sobre espólio não cerâmico recuperado no Largo de Jesus (Lisboa) Carlos Boavida

1815 Adereços de vidro, dos séculos XVI-XVIII, procedentes do antigo Convento de Santana de Lisboa (anéis, braceletes e contas)

Joana Gonçalves / Rosa Varela Gomes / Mário Varela Gomes

1837 Da ostentação, luxo e poder à simplicidade do uso quotidiano: arqueologia e simbologia de joias e adornos da Idade Moderna Portuguesa Jéssica Iglésias

1849 Os amuletos em Portugal - dos objetos às superstições: o coral vermelho Alexandra Vieira

1865 Cerâmicas de Vila Franca de Xira nos séculos XV e XVI Eva Pires

1879 «Não passa por teu o que me pertence». Marcas de individualização associadas a faianças do Convento de Nossa Senhora de Aracoeli, Alcácer do Sal Catarina Parreira / Íris Fragoso / Miguel Martins de Sousa

1891 Cerâmica de Leiria: alguns focos de produção

Jaqueline Pereira / André Donas-Botto

1901 Os Fornos na Rua da Biquinha, em Óbidos Hugo Silva / Filipe Oliveira

1909 A casa de Pêro Fernandes, contador dos contos de D. Manuel I: o sítio arqueológico da Silha do Alferes, Seixal (século XVI) Mariana Nunes Ferreira

1921 O Alto da Vigia (Sintra) e a vigilância e defesa da costa Alexandre Gonçalves / Sandra Santos

1937 O contexto da torre sineira da Igreja de Santa Maria de Loures Paulo Calaveira / Martim Lopes

1949 A Necrópole do Hospital Militar do Castelo de São Jorge e as práticas funerárias na Lisboa de Época Moderna Susana Henriques / Liliana Matias de Carvalho / Ana Amarante / Sofia N. Wasterlain

1963 SAND - Sarilhos Grandes Entre dois Mundos: o adro da Igreja e a Paleobiologia dos ossos humanos recuperados

Paula Alves Pereira / Roger Lee Jesus / Bruno M. Magalhães

1975 Expansão urbana da vila de Cascais no século XVII e XVIII: a intervenção arqueológica na Rua da Vitória no 15 a 17

Tiago Pereira / Vanessa Filipe

1987 Novos dados para o conhecimento do Urbanismo de Faro em época Moderna Ana Rosa 
1995 Um exemplo de Arqueologia Urbana em Alcoutim: o Antigo Edifício dos CTT Marco Fernandes / Marta Dias / Alexandra Gradim / Virgílio Lopes / Susana Gómez Martínez

2007 Palácio dos Ferrazes (Rua das Flores/Rua da Vitória, Porto): a cocheira de Domingos Oliveira Maia

Francisco Raimundo

2021 As muitas vidas de um edifício urbano: História, Arqueologia e Antropologia no antigo Recreatório Paroquial de Penafiel Helena Bernardo / Jorge Sampaio / Marta Borges

2035 O convento de Nossa Senhora da Esperança de Ponta Delgada: o contributo da arqueologia para o conhecimento de um monumento identitário João Gonçalves Araújo / N’Zinga Oliveira

2047 Arqueologia na ilha do Corvo... em busca da capela de Nossa Senhora do Rosário Tânia Manuel Casimiro / José Luís Neto / Luís Borges / Pedro Parreira

2059 Perdidos à vista da Costa. Trabalhos arqueológicos subaquáticos na Barra do Tejo Jorge Freire / José Bettencourt / Augusto Salgado

2071 Arqueologia marítima em Cabo Verde: enquadramento e primeiros resultados do projecto CONCHA

José Bettencourt / Adilson Dias / Carlos Lima / Christelle Chouzenoux / Cristóvão Fonseca / Dúnia Pereira / Gonçalo Lopes / Inês Coelho / Jaylson Monteiro / José Lima / Maria Eugénia Alves / Patrícia Carvalho / Tiago Silva

2085 Trabalhos arqueológicos na Cidade Velha (Ribeira Grande de Santiago, Cabo Verde): reflexões sobre um projecto de investigação e divulgação patrimonial André Teixeira / Jaylson Monteiro / Mariana Mateus / Nireide Tavares / Cristovão Fonseca / Gonçalo C. Lopes / Joana Bento Torres / Dúnia Pereira / André Bargão / Aurélie Mayer / Bruno Zélie / Carlos Lima / Christelle Chouzenoux / Inês Henriques / Inês Pinto Coelho / José Lima / Patrícia Carvalho / Tiago Silva

2103 A antiga fortificação de Quelba / Khor Kalba (E.A.U.). Resultados de quatro campanhas de escavações, problemáticas e perspectivas futuras Rui Carita / Rosa Varela Gomes / Mário Varela Gomes / Kamyar Kamyad

2123 Colónias para homens novos: arqueologia da colonização agrária fascista no noroeste ibérico Xurxo Ayán Vila / José Mạ . Señorán Martín 


\title{
PATRIMÓNIO ARQUEOLÓGICO E GESTÃO TERRITORIAL: O CONTRIBUTO DA ARQUEOLOGIA PARA A REVISÃO DO PDM DE AVIS
}

\author{
Ana Cristina Ribeiro ${ }^{1}$
}

\begin{abstract}
RESUMO
O diagnóstico actual da Arqueologia no concelho de Avis reflecte um conhecimento profundo e sistemático do território, das suas particularidades e da diversidade de expressões que traduzem a ocupação humana nesta região, preconizando a necessidade premente de se efectivar a revisão do Plano Director Municipal.

Apresenta-se uma síntese do contributo do Centro de Arqueologia de Avis para o estudo e a salvaguarda do património arqueológico, abordando as opções estratégicas e os procedimentos considerados fundamentais para uma intervenção municipal face aos novos desafios que se colocam na gestão desses valores patrimoniais e na sua afirmação nas dinâmicas locais, que passa pela inserção nas políticas e nos instrumentos de gestão e ordenamento do território e nas estratégias de desenvolvimento local.
\end{abstract}

Palavras-chave: Território, Património arqueológico, Gestão integrada, Salvaguarda, Revisão do PDM.

\begin{abstract}
The current diagnosis of Archaeology in the municipality of Avis reflects a deep and systematic knowledge of the territory, its particularities and the diversity of expressions that translate the human occupation in this region, advocating the urgent need to revise the Municipal Master Plan.

A summary of the contribution of the Avis Archaeology Centre to the study and safeguarding of archaeological heritage is presented, addressing the strategic options and procedures considered fundamental for a municipal intervention in the face of the new challenges in the management of these heritage values and their affirmation in local dynamics, which includes insertion in the politics and instruments of management and planning of the territory and in local development strategies.
\end{abstract}

Keywords: Territory, Archaeological heritage, Integrated management, Safeguarding, Review of the PDM.

\section{INTRODUÇÃO}

As autarquias, enquanto promotoras da actividade arqueológica, têm um papel determinante na salvaguarda, estudo e valorização do património arqueológico local. Contudo, a expressão desse contributo é condicionada pela sensibilidade e vontade do poder local, determinando o reconhecimento da Arquelogia e assim das estruturas, das equipas, dos recursos e dos meios disponíveis para o desenvolvimento de trabalhos arqueológicos, assim como da concretização de medidas de salvaguarda e valorização.

Apesar de deter um nível de intervenção privilegiado enquanto agentes locais, acedendo de forma directa ao património arqueológico e estabelecendo, simultaneamente, uma relação próxima com a comunidade, o facto é que a arqueologia nem sempre é uma prioridade das autarquias, uma vez que o património arqueológico continua a ser encarado como um obstáculo que condiciona o desenvolvimento local. Consequentemente, um dos maiores desafios que se impõe à arqueologia municipal é consciencializar para a importância da salvaguarda dos valores patrimoniais, demonstrando que, quando devidamente geridos, podem contribuir para o desenvolvimento local, pelo que é fundamental definir e

1. Centro de Arqueologia de Avis; ana.ribeiro@cm-avis.pt 
implementar mecanismos adequados de avaliação e intervenção preventivas.

Por conseguinte, a existência de valores arqueológicos associados a um território implica uma responsabilidade acrescida ao nível da gestão municipal, que se efectiva na implementação de um conjunto de meios e instrumentos que promovem o estudo, a salvaguarda e a valorização desse património.

Embora o panorama, em diversos casos, não se afigure o mais favorável, o facto é que a arqueologia municipal tem vindo a adquirir uma expressão significativa que se manifesta em diversos exemplos.

A criação de estruturas orgânicas com atribuições relacionadas com a prática arqueológica, desenvolvida por arqueólogos em regime de continuidade e com relações laborais estáveis, e a crescente valorização do património arqueológico enquanto recurso local, têm contribuído para o crescimento e consolidação da arqueologia municipal.

Desta forma, são criadas as condições base para uma intervenção activa da arqueologia no planeamento e gestão do património arqueológico no âmbito dos instrumentos de gestão territorial que, consequentemente, irá refletir-se na criação de medidas de protecção e salvaguarda adequadas às realidades arqueológicas.

É neste contexto que se integra o caso de Avis, onde, a partir dos trabalhos desenvolvidos nos últimos anos, se definiu uma nova visão para o território e para o património arqueológico que assenta, não só na revisão de registos precedentes e na identificação de um número considerável de novos sítios, mas também no reconhecimento de novos focos de ameaça à integridade dos locais de interesse arqueológico e na necessidade de se implementarem estratégias revistas e actualizadas de protecção, gestão e valorização destes bens, em articulação com os demais recursos e factores territoriais.

Torna-se cada vez mais evidente a necessidade de conciliar, adequar e definir medidas de preservação e valorização desses valores que, por sua vez, induzem ao registo e estudo, criando-se uma base de trabalho que, para além do reforço e manutenção da identidade local, contribuem para a criação e renovação de uma oferta vocacionada para a dinamização cultural e turística, com repercussões nos planos sociais e, sobretudo, económico.

\section{INSTRUMENTOS DE GESTÃO TERRITO- RIAL E PATRIMÓNIO ARQUEOLÓGICO EM AVIS: UM BREVE ENQUADRAMENTO}

O reconhecimento da importância dos valores patrimoniais reflecte-se, em Avis, na elaboração, no início da década de 8 o do século XX, de estratégias de identificação e avaliação do património cultural local, com vista à constituição de um inventário e à definição de acções de valorização.

Ao nível do património arqueológico, este trabalho reúne a bibliografia para o concelho de Avis e identifica os locais de interesse arqueológico, delineando propostas de intervenção futura com vista à sua valorização.

Este levantamento terá favorecido e facilitado, numa fase posterior, a integração do património arqueológico nos instrumentos de gestão do território (IGT) e a definição de normas regulamentares de protecção. O Plano de Urbanização de Avis (PU), publicado em 1994, é omisso relativamente ao património arqueológico, mas revela já alguma preocupação com os valores patrimoniais do núcleo urbano histórico de Avis. Para isso evoca o património edificado classificado, assinalando ainda valores edificados não classificados, mas de reconhecido valor patrimonial, para o qual são definidas normas específicas.

O Plano Director Municipal de Avis (PDM), de 1995, estabelece os condicionamentos decorrentes do regime de protecção do património, com a identificação do património edificado e arqueológico classificado existente no concelho. O regulamento abrange ainda os sítios arqueológicos incluídos na planta de condicionantes, correspondentes, à data da publicação, a 62 locais.

O património arqueológico figura igualmente nos Planos de Ordenamento das Albufeiras de Maranhão e de Montargil (POA), de 1999 e 2002. O POA de Maranhão é mais rigoroso na sua regulamentação, considerando, para efeitos de aplicação das normas de salvaguarda, o património arqueológico no plano de água, em meio submerso ou submersível, e na área envolvente, correspondente a uma faixa de $500 \mathrm{~m}$, prevendo medidas que visam a sua protecção e salvaguarda, aplicáveis aos sítios assinalados na planta de síntese ou aos que possam ser identificados posteriormente.

Em 2008 é publicado o Plano de Pormenor de Salvaguarda e Valorização do Centro Histórico de Avis (PPSVCHA), que implementa medidas que assegu- 
ram a salvaguarda dos valores arqueológico e fomentam a arqueologia de carácter preventivo na zona antiga da vila, acautelando-se que a eficácia das acções preventivas ultrapassa o acompanhamento de obras, permitindo, assim, uma maior participação da arqueologia na gestão e no planeamento urbanísticos.

Desta forma, procurou-se garantir a aplicação de medidas preventivas materializadas no âmbito de licenciamento de obras, na participação/consulta em fase prévia de projectos, e no acompanhamento arqueológico de obras, que constitui ainda a forma mais frequente de intervenção.

Após a conclusão do estudo que esteve na origem do PPSVCHA, desenvolvido entre 2002 e 2004, promoveu-se uma abordagem alargada ao concelho, com resultados que reclamam uma actualização urgente das normas de salvaguarda do património arqueológico local e a sua respectiva inserção nos IGT de Avis. (Quadro 1)

\section{UM DIAGNÓSTICO DO PATRIMÓNIO ARQUEOLÓGICO LOCAL}

A partir de 2005 fomenta-se uma estratégia continuada de levantamento e diagnóstico do património arqueológico local.

Nesse sentido, e de forma a criar uma visão global e integrada dos testemunhos de ocupação no concelho, foi iniciada a Carta Arqueológica de Avis (Ribeiro, 2008, p. 1-12).

Os dados reunidos anteriormente eram claramente insatisfatórios, atendendo à dimensão do território e às suas características naturais, deixando antever lacunas na identificação de sítios e levantando inúmeras questões relativas à ocupação humana, que careciam de uma abordagem mais aprofundada.

A Carta Arqueológica de Avis pretendia assim rever a informação já conhecida e definir estratégias que possibilitassem a identificação de novos sítios, actualizando o inventário e promovendo o estudo e a valorização do património arqueológico local.

A informação reunida veio contribuir para uma gestão integrada destes valores no território e, desta forma, para a participação nas dinâmicas de desenvolvimento local.

A visão fraccionada e incompleta que existia no início do projecto foi-se atenuando à medida que os trabalhos se desenvolviam.

A identificação de um conjunto significativo de sítios e monumentos arqueológicos inéditos demonstrou que a realidade era bem mais variada e multifacetada do que a que se conhecia no início da Carta Arqueológica, cujo quadro de referência, reunido no PDM, incluía 62 locais de interesse arqueológico. No final da Carta Arqueológica de Avis, o inventário incluía 205 sítios registados. (Gráficos 1 e 2)

Actualmente, o inventário de sítios aqueológicos reúne 335 ocorrências para o concelho, resultantes de trabalhos mais recentes associados ao projecto “Territórios e espaços de morte na pré-história recente-TEMPH” (idem, 2018a p.73-94; idem, 2018b, p. 83-10o).

Dos dados reunidos, 65 correspondem a sítios relocalizados, referenciados em trabalhos precedentes, sendo os restantes 269 locais inéditos. (Gráfico 3 ) Neste processo de incremento da actividade arqueológica em Avis, a acção preventiva assumiu um papel igualmente importante. Com o objectivo de minimizar o impacto decorrente da realização de obras em locais ou imóveis com sensibilidade arqueológica, procurou-se envolver a arqueologia, com o devido enquadramento no PPSVCHA, nas intervenções em áreas de reconhecido ou potencial valor patrimonial. Para além dos resultados obtidos, que têm permitido alargar o conhecimento sobre a ocupação da zona antiga de Avis, a intervenção da arqueologia tem vindo a afirmar-se, ainda que com alguns constrangimentos, no âmbito do licenciamento de obras públicas e particulares, na fiscalização, na participação na revisão dos instrumentos de gestão territorial e na consulta na fase de elaboração de projectos.

Consciente das competências das autarquias em matéria de património, e num contexto favorável à actividade arqueológica em Avis (idem, 2011, 567588), foi criado, em 2011 o Centro de Arqueologia de Avis (CAA), serviço municipal que tem procurado despoletar mecanismos actualizados e revistos de avaliação e intervenção preventivas aplicados ao património arqueológico, assegurando a sua identificação, inventário, estudo, salvaguarda e divulgação (idem, 2012, p. 191-193).

No âmbito da sua actuação, o CAA tem, ao nível do planeamento e do ordenamento do território, um papel fundamental no reconhecimento do potencial património arqueológico existente no concelho e na promoção do seu estudo e enquadramento territorial, fomentando meios de gestão que procuram assegurar a sua protecção e salvaguarda em articulação com o território.

A organização da informação resultante dos diver- 
sos trabalhos assume, neste contexto, particular relevo. A realização do Inventário Geral de Património Arqueológico de Avis (IGPAA) e o respectivo sistema de informação geográfica constituem um importante contributo para a gestão e valorização do património arqueológico local.

O IGPAA tem por base a ficha de sítio arqueológico, onde se reúnem os critérios descritivos fundamentais para a caracterização individualizada dos sítios. Associados a cada uma das fichas estão outros ficheiros com informação complementar.

As fichas de sítio estão correlacionadas com a cartografia SIG, desenvolvida com base nas folhas das Cartas Militares de Portugal, à escala 1:25 000. Perspectivando-se o melhoramento da base georreferenciada com a integração de cartografia actualizada, assim como de novos elementos de análise, será possível, em breve, tornar mais eficaz a leitura global do território.

Com esta base de trabalho tem sido possível proceder à sistematização dos locais de interesse arqueológico, aspecto preponderante na gestão integrada do território e nas dinâmicas culturais e turísticas. (Quadro 2)

\section{CONTRIBUTO DA ARQUEOLOGIA NA REVISÃO DO PDM DE AVIS}

Com a revisão de dados e a identificação de novos testemunhos de ocupação do território verificou-se, a partir de 2005, um aumento considerável dos valores arqueológicos inventariados, que se devem, em grande medida, à Carta Arqueológica de Avis e, posteriormente, ao projecto TEMPH.

Mas, se por um lado se verificou um acréscimo de sítios de interesse arqueológico, por outro lado identificaram-se novos factores que ameaçam a sua integridade, decorrentes do ritmo acelerado das transformações da paisagem e do território, verificado há mais de uma década, na sequência da implementação da produção agrícola em regime intensivo.

Perante o actual quadro de referência do património arqueológico de Avis, importa pois reflectir e, consequentemente, agir preventivamente no que diz respeito às medidas de salvaguarda a aplicar, em particular no que se refere aos locais que não se encontram integrados no PDM ou que não estão classificados, em vias de classificação ou em área de servidão administrativa de proteção a bens culturais imóveis. Neste âmbito, a inventariação dos valores patrimo- niais decorrente dos trabalhos realizados assume especial relevo, para o processo de revisão do PDM, uma vez que fornece uma visão global sobre as realidades e o potencial arqueológico do concelho, identifica aptidões e avalia possíveis interferências. O inventário constitui, por isso, a base para o desenvolvimento de acções que promovam a sua salvaguarda, gestão e valorização em coerência com os restantes recursos territoriais.

Em 2019, e no âmbito do Relatório do Estado do Ordenamento do Território (REOT), onde se definiu o enquadramento estratégico que fundamentará a necessidade de revisão do PDM de Avis, o CAA realizou um diagnóstico síntese do património arqueológico do concelho integrado no IGPAA, e estabeleceu as linhas orientadoras de medidas de salvaguarda do património arqueológico adequadas, sublinhando a necessidade de se regulamentar a avaliação e $\mathrm{a}$ intervenção preventivas.

Os trabalhos desenvolvidos permitiram definir categorias patrimoniais e actualizar a sua distribuição geográfica, associada a dois contextos diferenciados, correspondentes aos núcleos urbanos e ao meio rural. Com esta distinção procurou-se qualificar, de forma adequada às respectivas particularidades, as opções estratégicas e os procedimentos metodológicos e técnicos a adoptar na implementação de medidas de salvaguarda.

Esta orientação permitirá também gerir, de forma mais eficaz, o desenvolvimento dos sectores económicos predominantes em cada um desses contextos, em harmonia com o património arqueológico existente, garantindo a minimização de impactos sobre a informação que confere identidade a este território. Para os núcleos urbanos, encontram-se regulamentadas, através do PPSVCHA, normas de protecção do património arqueológico aplicáveis ao Centro Histórico de Avis.

No entanto, e considerando a antiguidade de ocupação da maioria dos restantes núcleos urbanos do concelho, entende-se pertinente a definição de zonamentos que correspondam a diferentes áreas de protecção com as respectivas normas de salvaguarda. No que se refere ao património arqueológico em meio rural, contexto onde se verifica um claro predomínio de sítios arqueológicos, foram identificados diferentes níveis de valor patrimonial.

Assim, e com base no reconhecimento da existência de diversas realidades, considera-se que, ao nível do património arqueológico neste contexto, deverá 
ser assegurada, no âmbito da revisão do PDM, a valoração dos locais de interesse arqueológico, à qual deverão corresponder diferentes graus de proteção e normas de salvaguarda.

Esta categorização será definida com base no tipo de sítio e terá em consideração a avaliação patrimonial, realizada no decurso dos trabalhos promovidos pelo CAA e cujos critérios se encontram assinalados na ficha de sítio. Deste modo, será possível definir zonas de protecção para os sítios, determinar medidas preventivas de acordo com o potencial arqueológico associada ao tipo de sítio e identificar condições de intervenção.

A aplicação de medidas preventivas deverá ser igualmente acautelada para o património arqueológico submerso ou submersível, associado aos planos de água das albufeiras de Maranhão e Montargil, anteriormente preconizadas com os respectivos POA, assim como para os achados arqueológicos ocasionais, evitando a destruição ou a dispersão de testemunhos arqueológicos.

Considerando a actividade continuada desenvolvida pelo CAA, é expectável a identificação de novas realidades, assim como a revisão de dados. Por conseguinte, e tendo em consideração a necessidade de se acautelar uma permanente actualização do inventário do património local, deverá ser contemplada a integração de novos sítios arqueológicos, sujeitando-se à regulamentação dos planos em vigor.

A nova redacção do PDM deverá, por isso, contemplar a aplicação das medidas de salvaguarda do património arqueológico aos sítios que venham a ser identificados após a sua publicação.

Com a consolidação de um serviço municipal como o CAA, tem sido garantido, de forma sistemática, o estudo, a salvaguarda e a valorização do património arqueológico local.

Os projectos de investigação têm assegurado o estudo continuado do território, com a permanente revisão e actualização da informação face à descoberta de novas realidades.

A acção preventiva, aplicada sobretudo à área abrangida pelo PPSVCHA, assim como a participação nos processos de licenciamento, no âmbito do enquadramento no PDM ou PPSCHA, têm determinando, embora de forma não constante, uma avaliação arqueológica dos impactos das operações urbanísticas, agrícolas e florestais.

Não menos importantes são as componentes de valorização e divulgação, pois é através destas acções que se promove uma consciencialização para a importância da preservação dos valores patrimoniais. Por essa razão, o CAA tem desenvolvido diversas iniciativas que asseguram um contacto permanente com a comunidade e com um público diversificado. Ainda neste âmbito, foi implementado, em 2016, o Plano de Gestão e Valorização de Sítios e Monumentos Arqueológicos (Ribeiro, 2017, p33-42), ferramenta essencial para a definição de estratégias de intervenção que visam a conservação e divulgação do património arqueológico.

Pelo trabalho desenvolvido, o contributo do CAA na gestão do património local e nas opções estratégicas para o desenvolvimento do concelho, é determinante para a manutenção dos factores distintivos e genuínos que conferem a este território singularidade, os quais, se devidamente valorizados, poderão contribuir significativamente para o turismo cultural e dinamismo socioeconómico local.

O CAA tem assegurado o diagnóstico permanente do património arqueológico do concelho, reconhecendo o seu potencial, a natureza e o grau das ameaças, assim como tem avaliado e definido as medidas que deverão ser adoptadas para contribuir para a preservação dos bens patrimoniais.

Porém, e no contexto actual, é cada vez mais expressiva a alteração, profunda e acelerada, da paisagem agrícola com a expansão das produções em regime intensivo nesta região, que tendem a descaracterizar este território, e em particular em Avis, onde a disponibilidade de recursos hídricos associados à albufeira de Maranhão, tem favorecido o crescimento desregulado deste modo de produção.

No sentido de minimizar os impactos negativos associados a esta prática crescente, a revisão do PDM constitui uma excelente oportunidade para se definirem medidas actualizadas e adaptadas a esta nova realidade, conferindo à autarquia, de acordo com as suas competências, um papel activo e interventivo na gestão dos recursos locais.

Por essa razão, mais do que normas e condicionantes de protecção, é necessário fazer verter no regulamento do PDM, ainda que previstos na lei geral, códigos de conduta adaptados às realidades locais, na relação actividade humana versus património e o recíproco.

O CAA reúne o conhecimento e dispõe das condições essenciais para contribuir, de forma decisiva, para a elaboração do estudo de caracterização territorial integrado na revisão do PDM de Avis, crian- 
do simultaneamente as condições para uma maior participação nas estratégias municipais relacionadas com o planeamento e ordenamento territoriais. Só através de uma articulação activa e constante com os restantes serviços municipais intervenientes nestas matérias será possível implementar, com a eficácia desejável, um conjunto de normas, procedimento e rotinas que assegurem a salvaguarda de uma herança comum, sendo expectável que os sucessivos executivos encarem esta valência e competência.

\section{BIBLIOGRAFIA}

ANASTÁCIO, Rita Ferreira; OOSTERBEEK, Luís e ROSINA, Pierluigi (2015) - Gestão integrada do território e do património: a importância dos sistemas de informação geográfica. Sémata, Ciências Sociais e Humana, vol. 27, pp. 187-197.

MARTINS, Ana Margarida Nunes (2011) - A salvaguarda do património cultural no ordenamento territorial. O caso específico do património arqueológico. Instituto de Ciências Jurídico-Políticas, Faculdade de Direito de Lisboa.

MIRANDA, Eduardo $\mathbb{E}$ alii (2011) - Instrumento para o planeamento e gestão do património: o caso de Évora. Actas do Encontro Arqueologia e Autarquias, Câmara Municipal de Cascais, pp. 13-39.

PEREIRA, Angelina Rosa Mateus (2018) - A salvaguarda do património arqueológico nos instrumentos de gestão territorial e regulamentos municipais do Algarve: dois casos de estudo. Faculdade de Letras da Universidade de Lisboa.

RIBEIRO, Ana Cristina (2018b) - O Complexo do Pedrogão no contexto das primeiras sociedades camponesas: breves notas sobre o povoamento neolítico no concelho de Avis. Revista de História e Economia. São Paulo/Lisboa, volume 21, pp. 83-10o.

RIBEIRO, Ana Cristina (2018a) - Território e espaços de morte na Pré-História Recente. Contributo para uma nova leitura do povoamento megalítico no concelho de Avis. Actas do VIII Encontro de Arqueologia do Sudoeste Peninsular. Serpa e Aroche. Câmara Municipal de Serpa, pp. 73-94.

RIBEIRO, Ana Cristina (2017) - Plano de Gestão e Valorização de Sítios e Monumentos Arqueológicos: um contributo para a salvaguarda do património megalítico de Avis. Al-madan Online, n. ${ }^{2}$, tomo 2, pp. 33-42.

RIBEIRO, Ana (2012) - Centro de Arqueologia de Avis: um novo impulso no estudo e na preservação do património arqueológico do Concelho. Al-madan Online, n. ${ }^{1}$ 17, tomo 1 , p. 191-193.

RIBEIRO, Ana Cristina (2011) - (Re)descobrir Avis. Contributo para o estudo e valorização do património arqueológico do concelho. Actas do Encontro Arqueologia e Autarquias. Câmara Municipal de Cascais, p. 567-588.
RIBEIRO, Ana Cristina (2008) - Uma primeira leitura da Carta Arqueológica de Avis. Al-madan Online, n.ำ 16, VII, p. 1-12. 


\begin{tabular}{lll}
\hline Ano & Medida & Descrição \\
\hline 1994 & Regulamentação & Plano de Urbanização \\
\hline 1995 & Regulamentação & Plano Director Municipal \\
\hline 1999 & Regulamentação & Plano de Ordenamento da Albufeira de Maranhão \\
\hline 2002 & Regulamentação & Plano de Ordenamento da Albufeira de Montargil \\
\hline 2008 & Regulamentação & $\begin{array}{l}\text { Plano de Pormenor de Salvaguarda e Valorização do Centro } \\
\text { Histórico de Avis }\end{array}$ \\
\hline
\end{tabular}

Quadro 1 - IGT de Avis com abrangência ao património arqueológico.

\begin{tabular}{|c|c|c|}
\hline Ano & Medida & Designação \\
\hline $2005-2009$ & Investigação & Carta Arqueológica de Avis \\
\hline 2006-2010 & Investigação & Intervenção Arqueológica no sítio da Ladeira, Ervedal ( $1^{\underline{a}}$ fase) \\
\hline $2010 / 2014$ & Investigação & Carta Arqueológica de Avis ( 2.. fase) \\
\hline $2014 / 2018$ & Investigação & $\begin{array}{l}\text { Território e espaços de morte na pré-história recente. } \\
\text { Contributo para o estudo do povoamento megalítico } \\
\text { no concelho de Avis (1. ․ fase) }\end{array}$ \\
\hline $\begin{array}{l}2012 / \\
\text { em curso }\end{array}$ & $\begin{array}{l}\text { Acção preventiva / } \\
\text { Investigação }\end{array}$ & $\begin{array}{l}\text { Intervenção arqueológica no Mosteiro de São Bento de Avis } \\
\text { - Conservação da Ala Poente do Claustro Velho e Espaços } \\
\text { Adjacentes }\end{array}$ \\
\hline Desde 2004 & $\begin{array}{l}\text { Avaliação } \\
\text { arqueológica }\end{array}$ & $\begin{array}{l}\text { Emissão de pareceres no âmbito do licenciamento de operações } \\
\text { urbanísticas e de enquadramento de actividade agrícola } \\
\text { e florestal }\end{array}$ \\
\hline Desde 2004 & Acção preventiva & $\begin{array}{l}\text { Intervenções diversas de carácter preventivo, com particular } \\
\text { incidência no Centro Histórico de Avis }\end{array}$ \\
\hline $2016 / 2019$ & Gestão e Valorização & $\begin{array}{l}\text { Plano de gestão e valorização de sítios e monumentos } \\
\text { arqueológicos_Património Megalítico (1. a fase) }\end{array}$ \\
\hline Em curso & $\begin{array}{l}\text { Inventário, gestão } \\
\text { e planeamento }\end{array}$ & $\begin{array}{l}\text { Reestruturação do Inventário geral do património arqueológico } \\
\text { de Avis (IGPAA) }\end{array}$ \\
\hline Em curso & $\begin{array}{l}\text { Inventário, gestão } \\
\text { e planeamento }\end{array}$ & Actualização da base SIG do IGPAA \\
\hline Em curso & $\begin{array}{l}\text { Inventário, gestão } \\
\text { e planeamento }\end{array}$ & Revisão do PDM de Avis \\
\hline Em curso & Investigação & $\begin{array}{l}\text { Território e espaços de morte na pré-história recente. } \\
\text { Contributo para o estudo do povoamento megalítico } \\
\text { no concelho de Avis ( } 2 .{ }^{\text {a }} \text { fase) }\end{array}$ \\
\hline
\end{tabular}

Quadro 2 - Principais acções desenvolvidas ao nível da gestão do património arqueológico em Avis. 


\section{Gráfico 1}

Registo de sítios arqueológicos

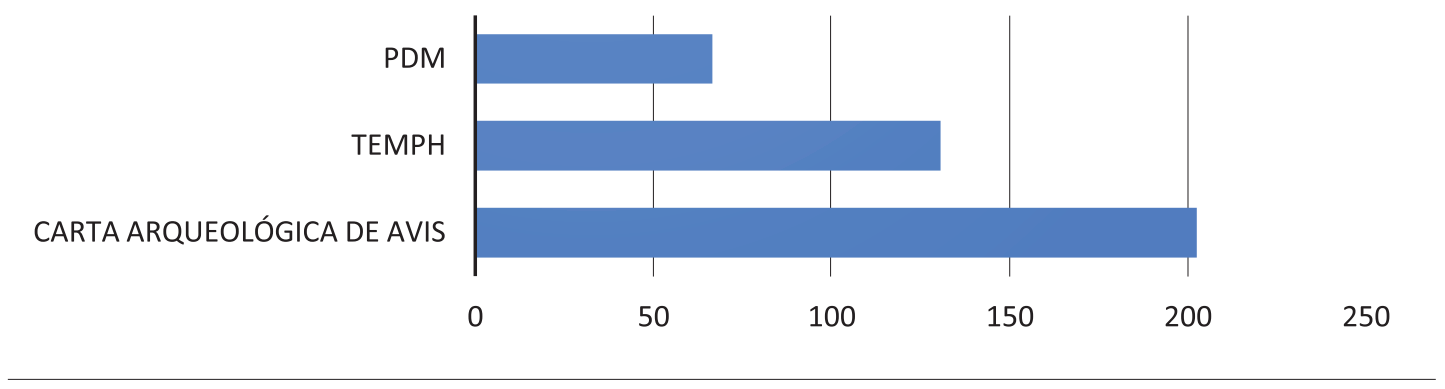

Gráfico 1 - Registo de sítios arqueológicos.

Gráfico 2

Registo de sítios arqueológicos

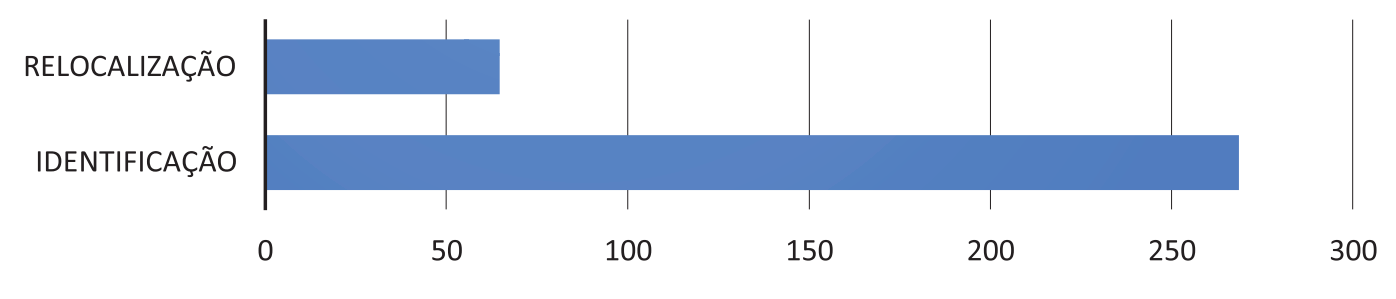

Gráfico 2 - Registo de sítios arqueológicos.

Gráfico 3

Distribuição dos sítios por freguesia

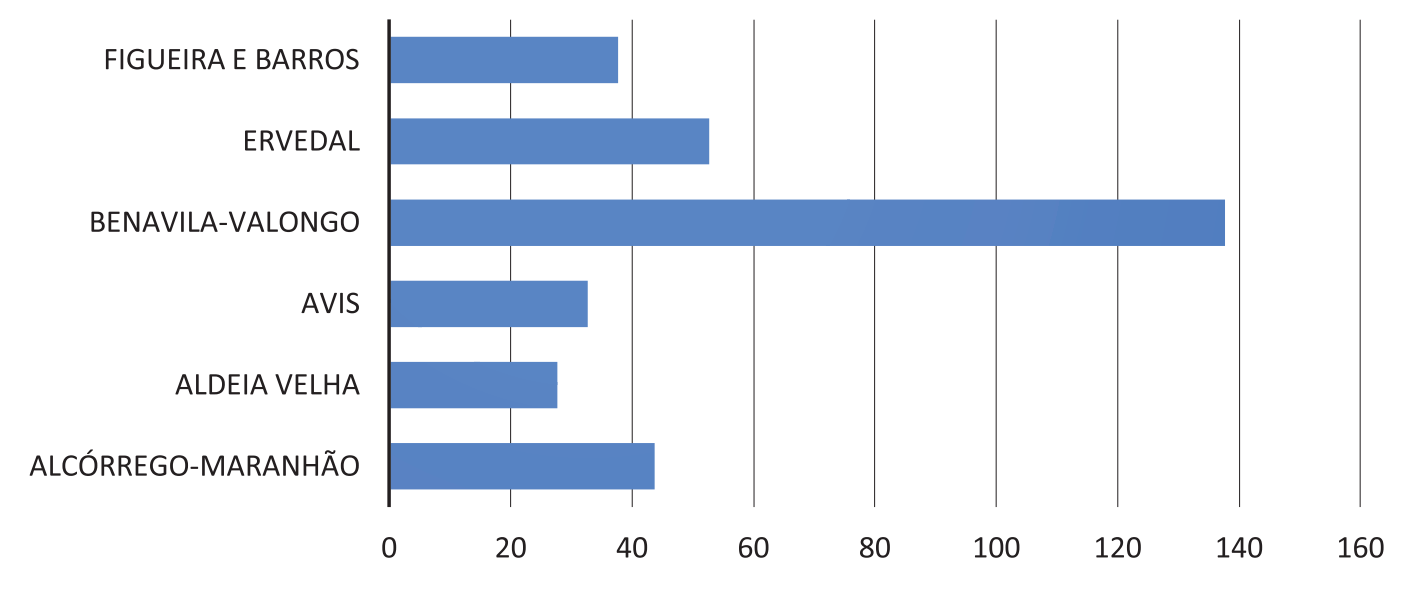

Gráfico 3 - Distribuição dos sítios por freguesia. 


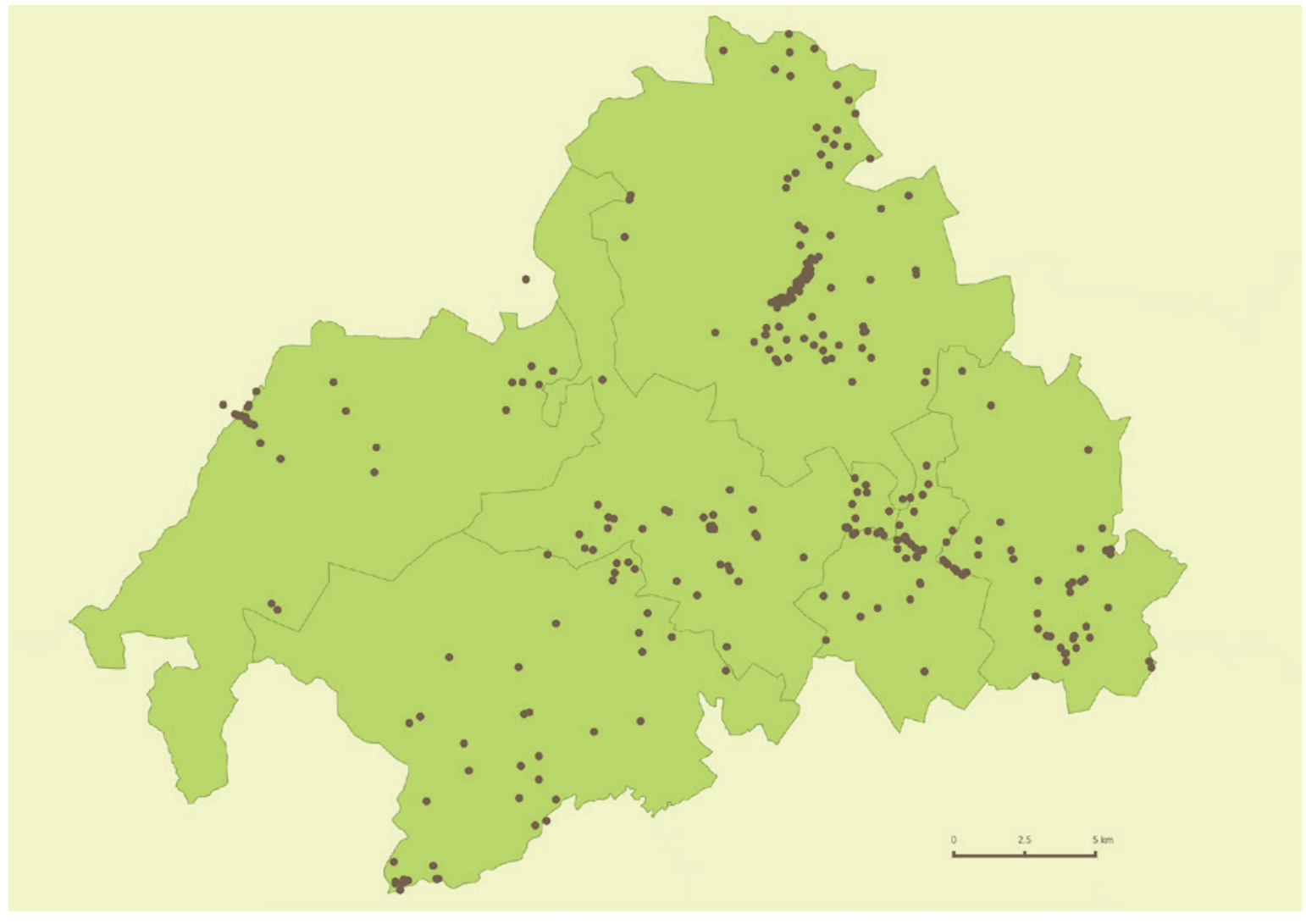

Figura 1 - Mapa síntese dos sítios integrados no Inventário Geral de Património Arqueológico de Avis.

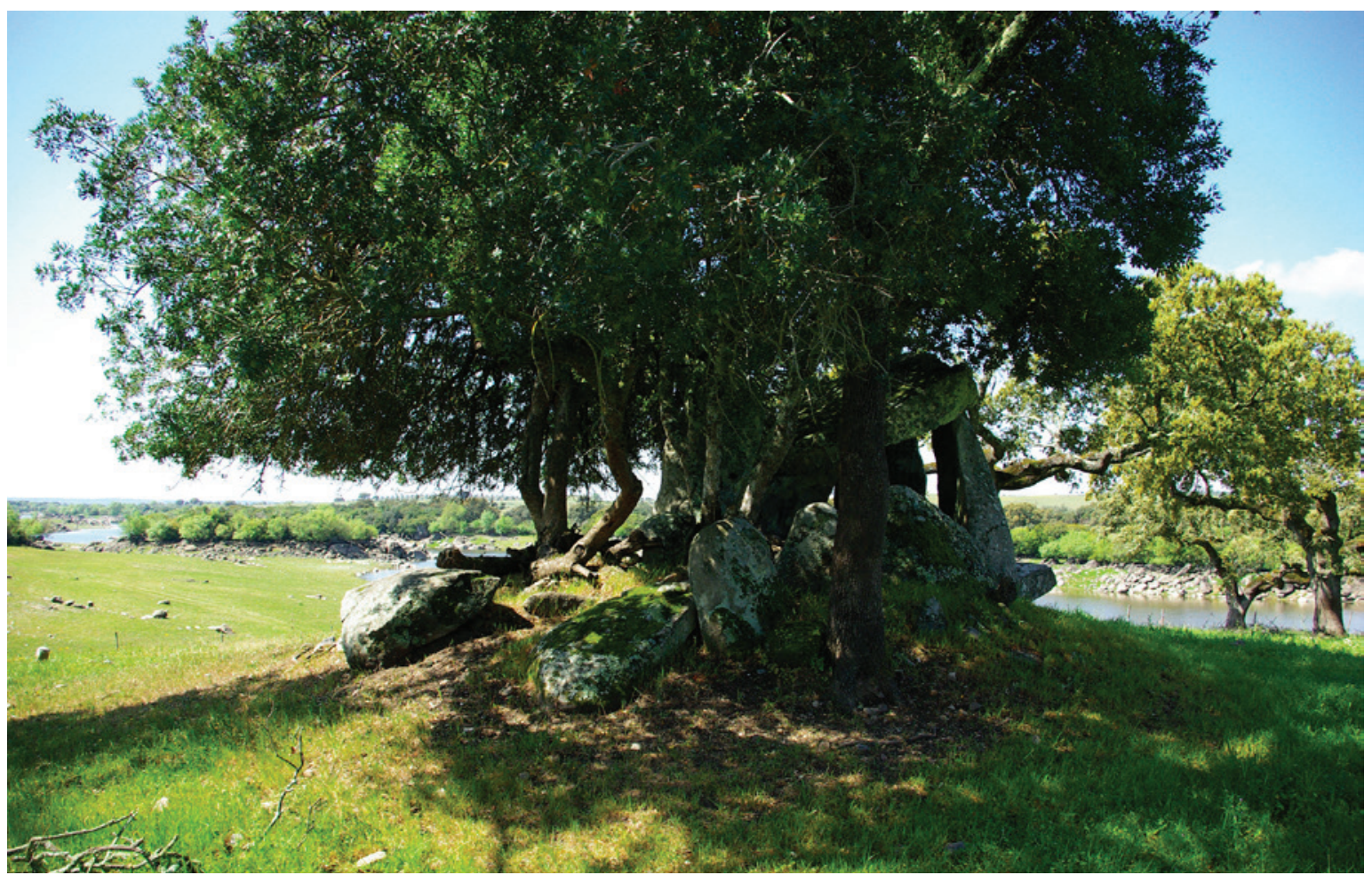

Figura 2 - Anta da Cumeada. 


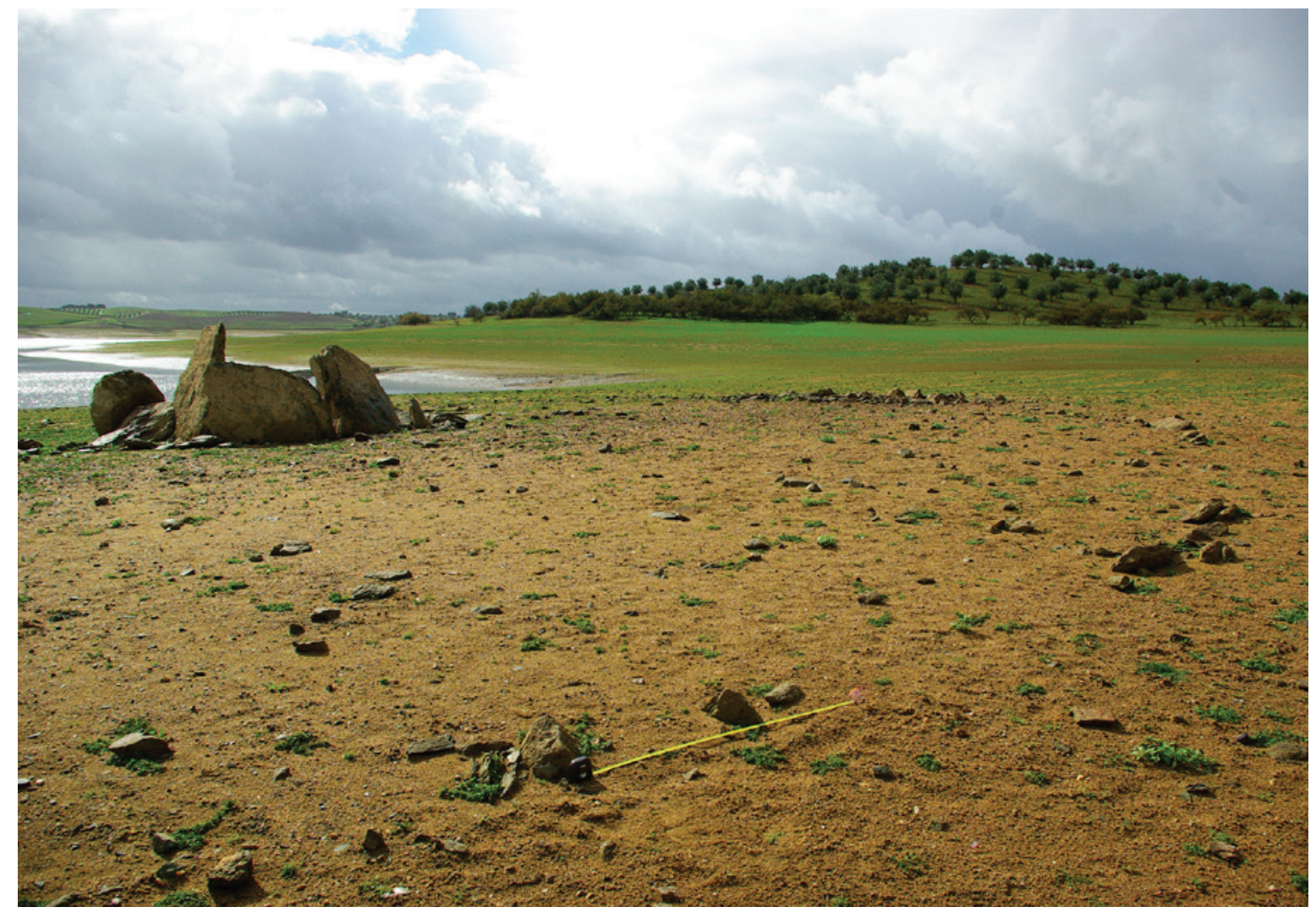

Figura 3 - Anta Rui Vaz 3.

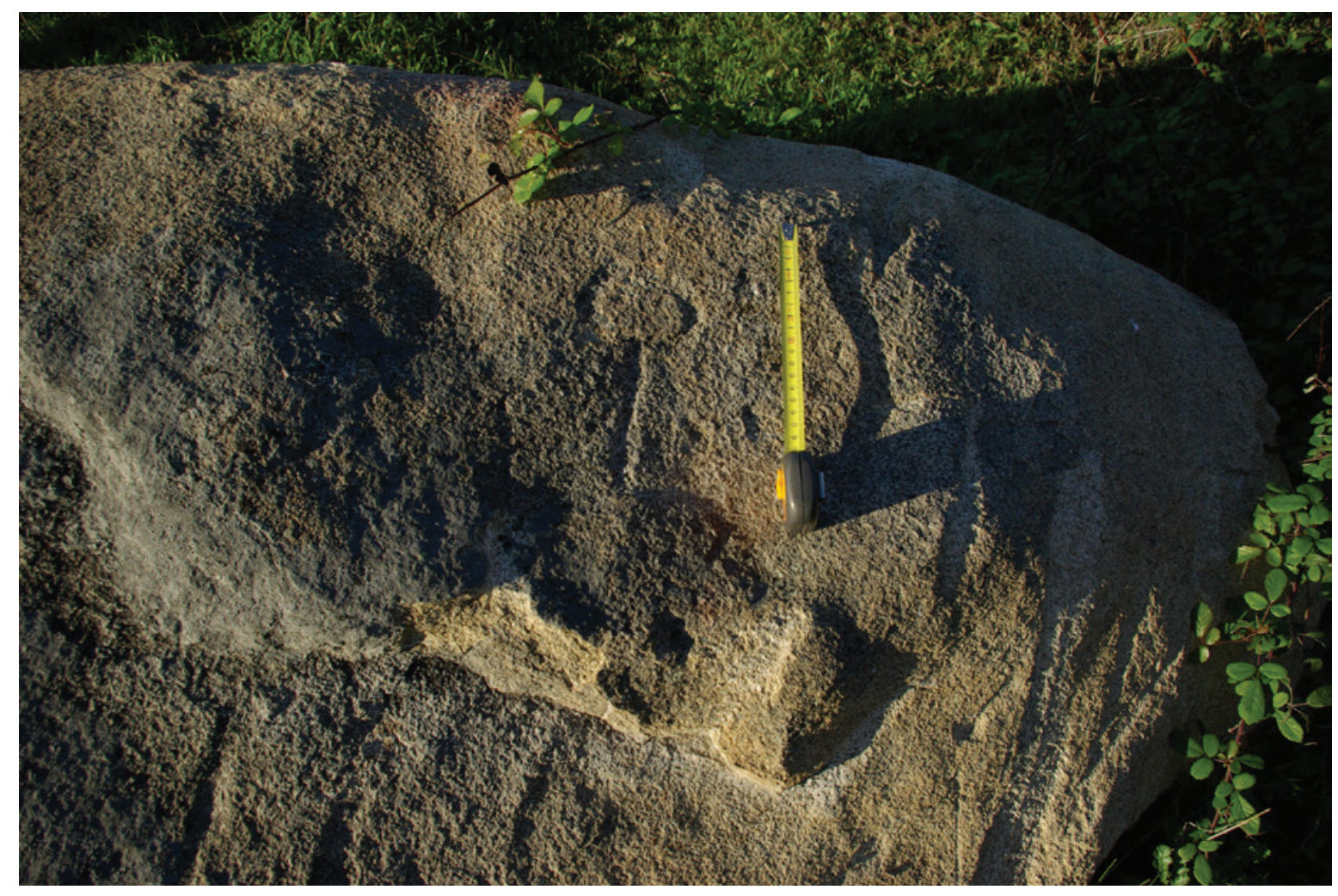

Figura 4 - Pormenor de monólito associado à Anta da Coutada. 


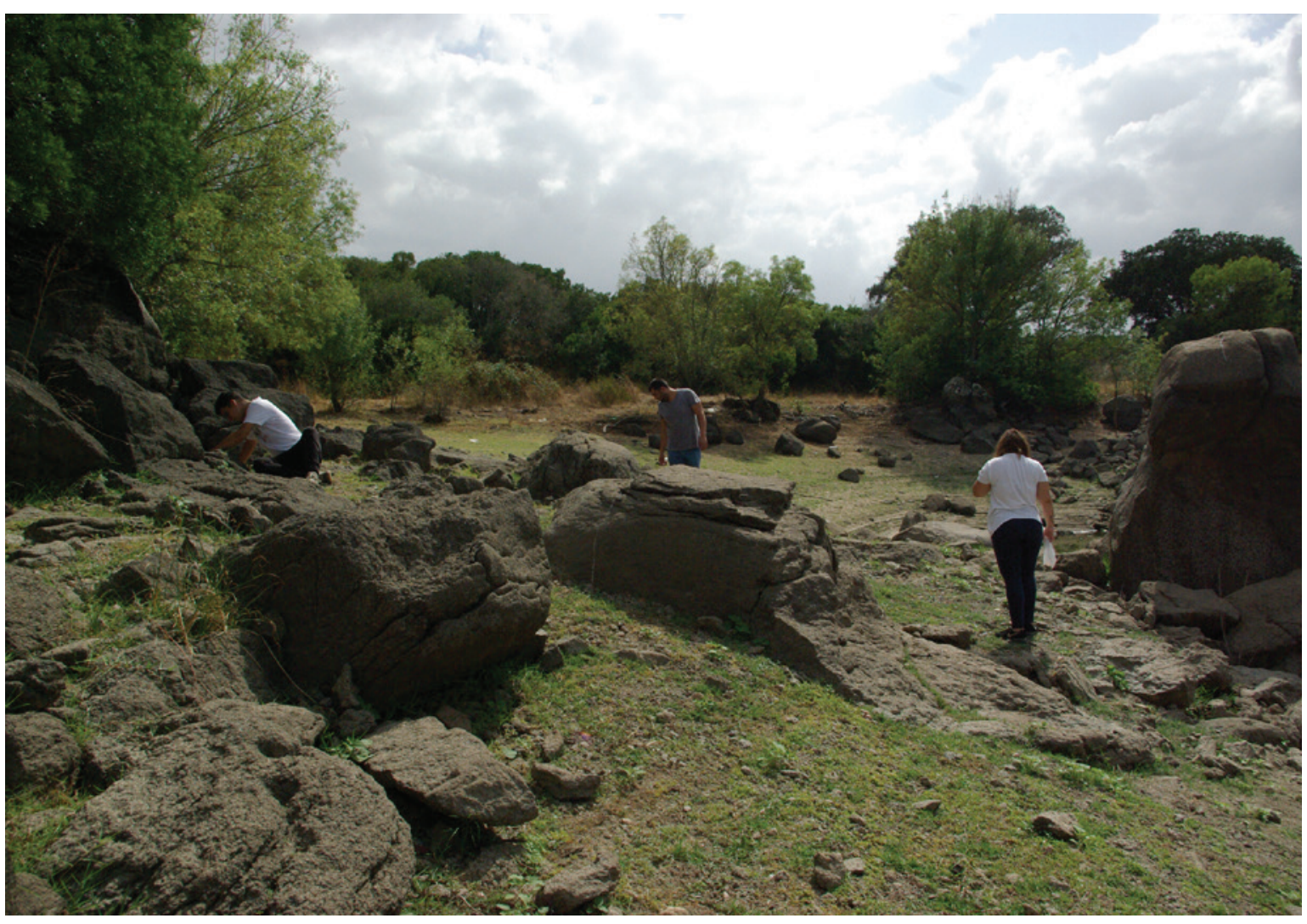

Figura 5- Trabalhos de prospecção no Complexo do Pedrogão. 


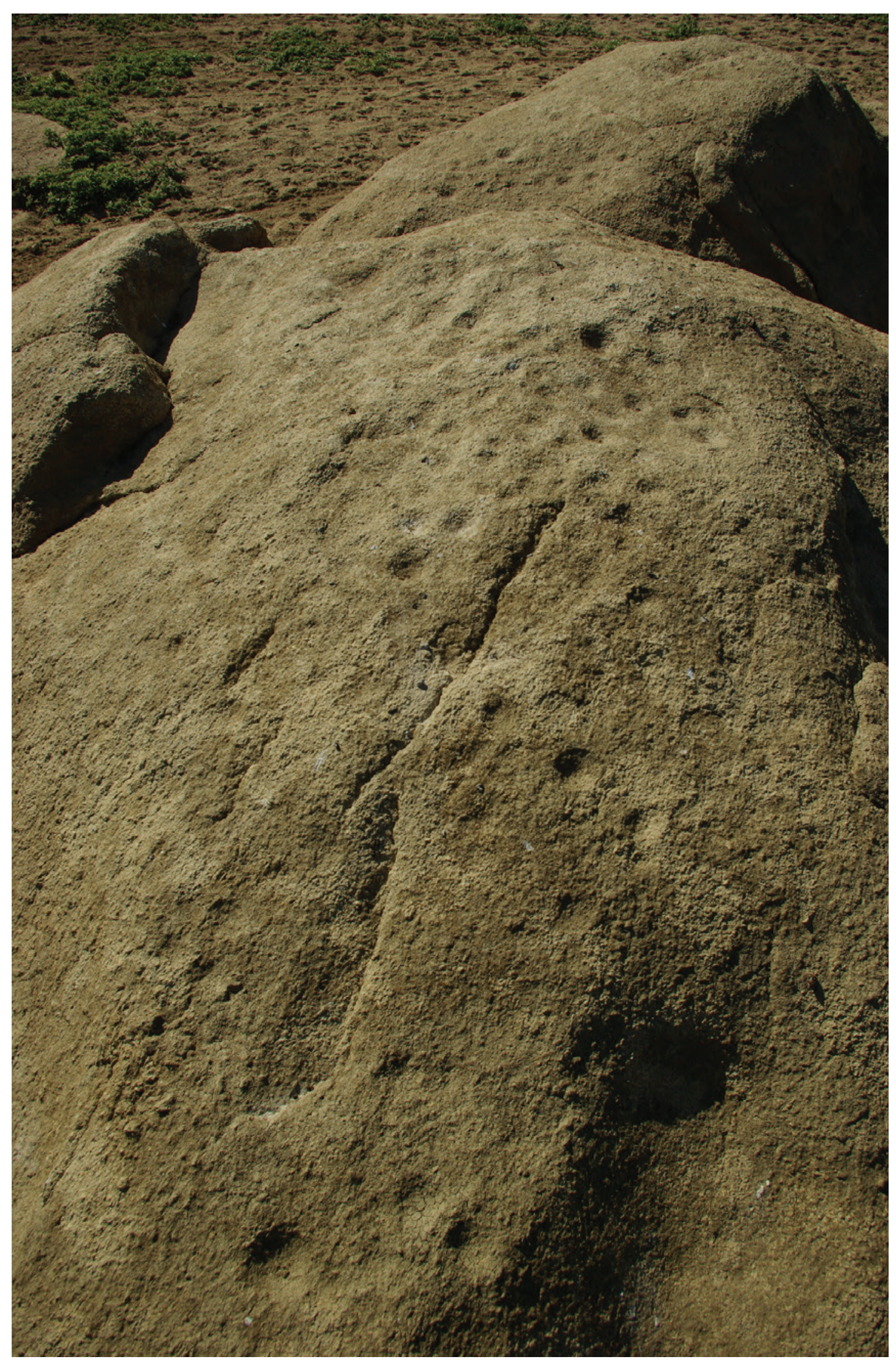

Figura 6 - Painel gravado. Horta das Rosas 7. 


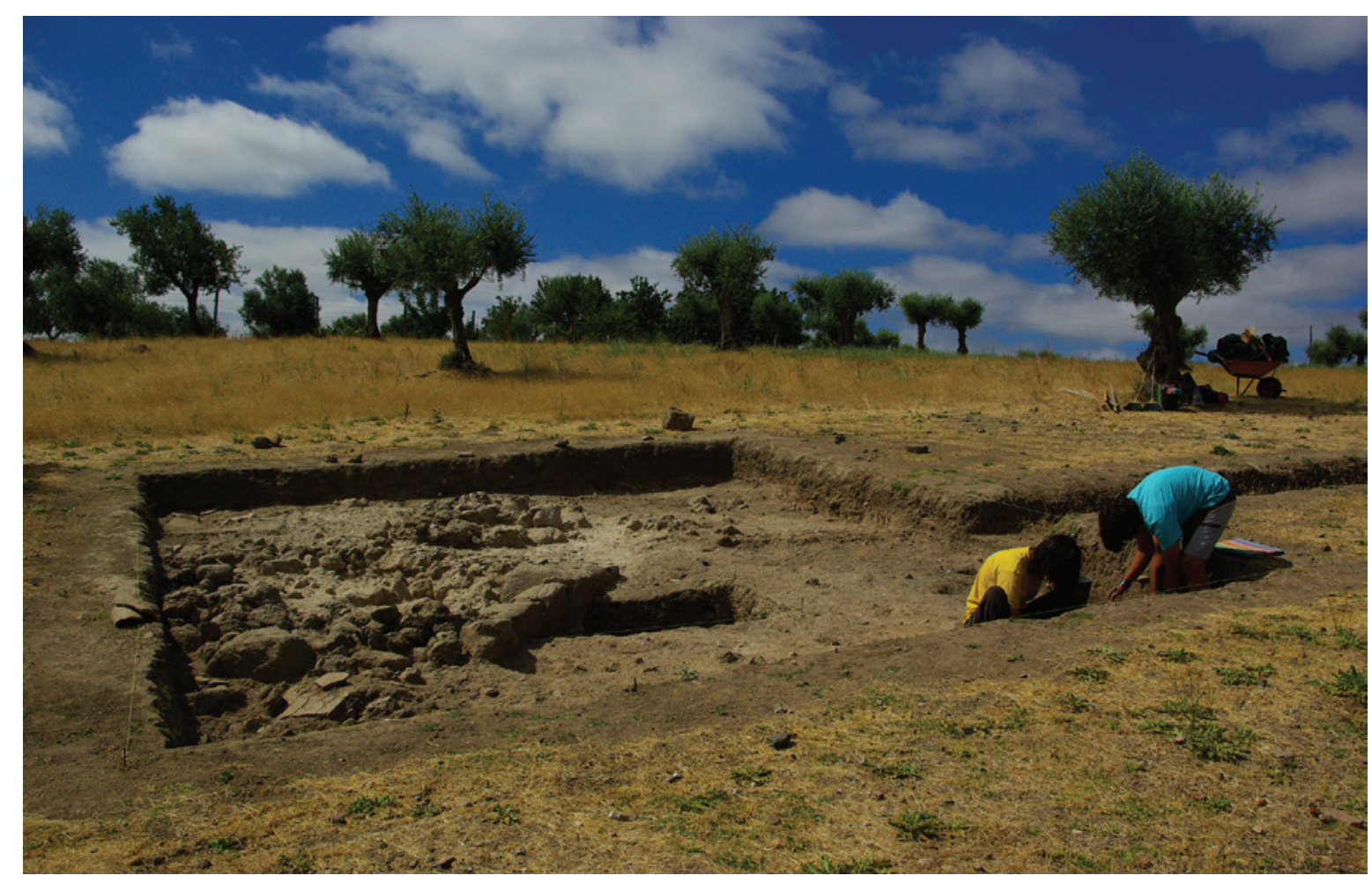

Figura 7 - Trabalhos de escavação no sítio da Ladeira.

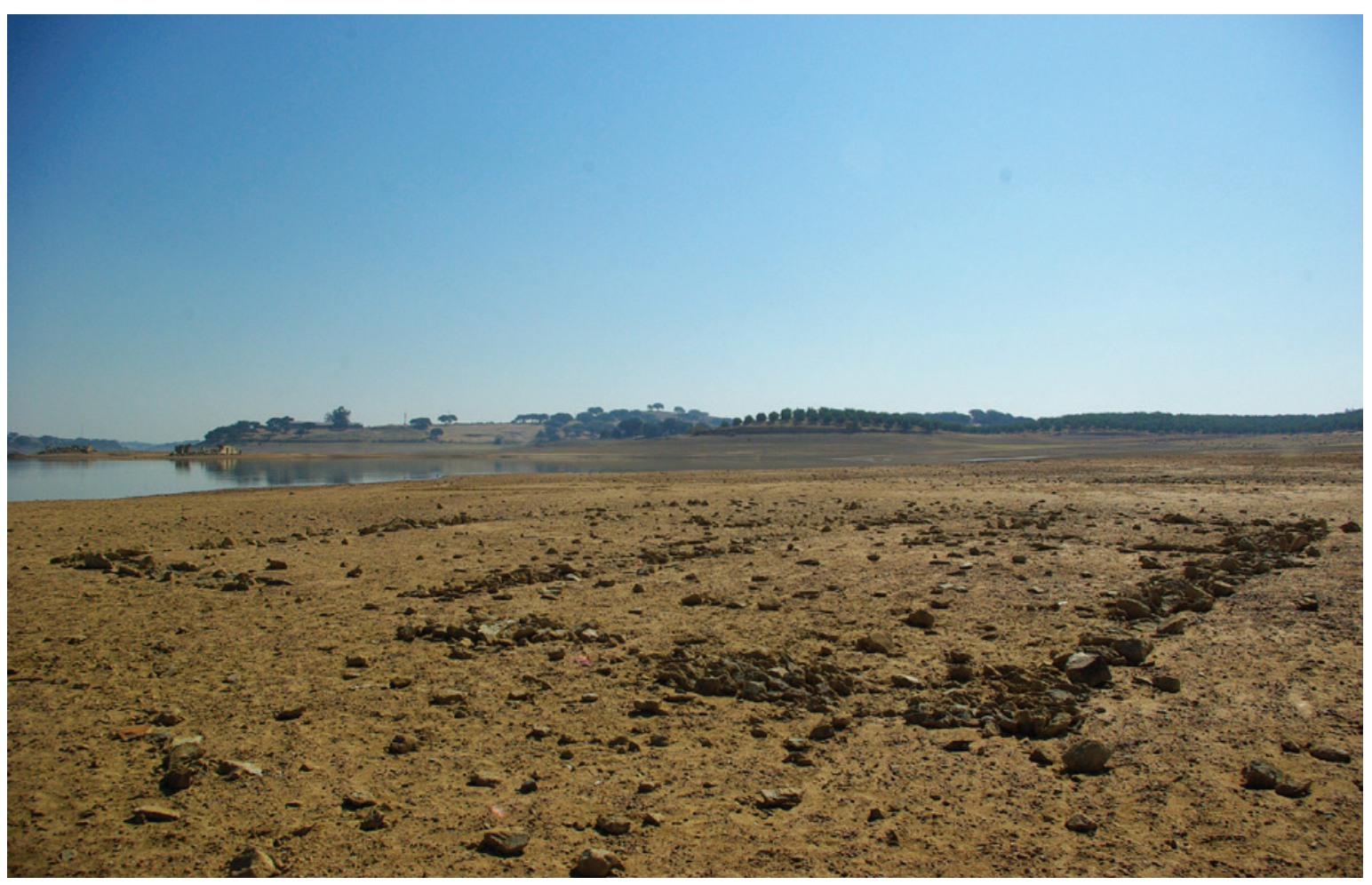

Figura 8 - Estruturas de período romano. Carapeta 3. 


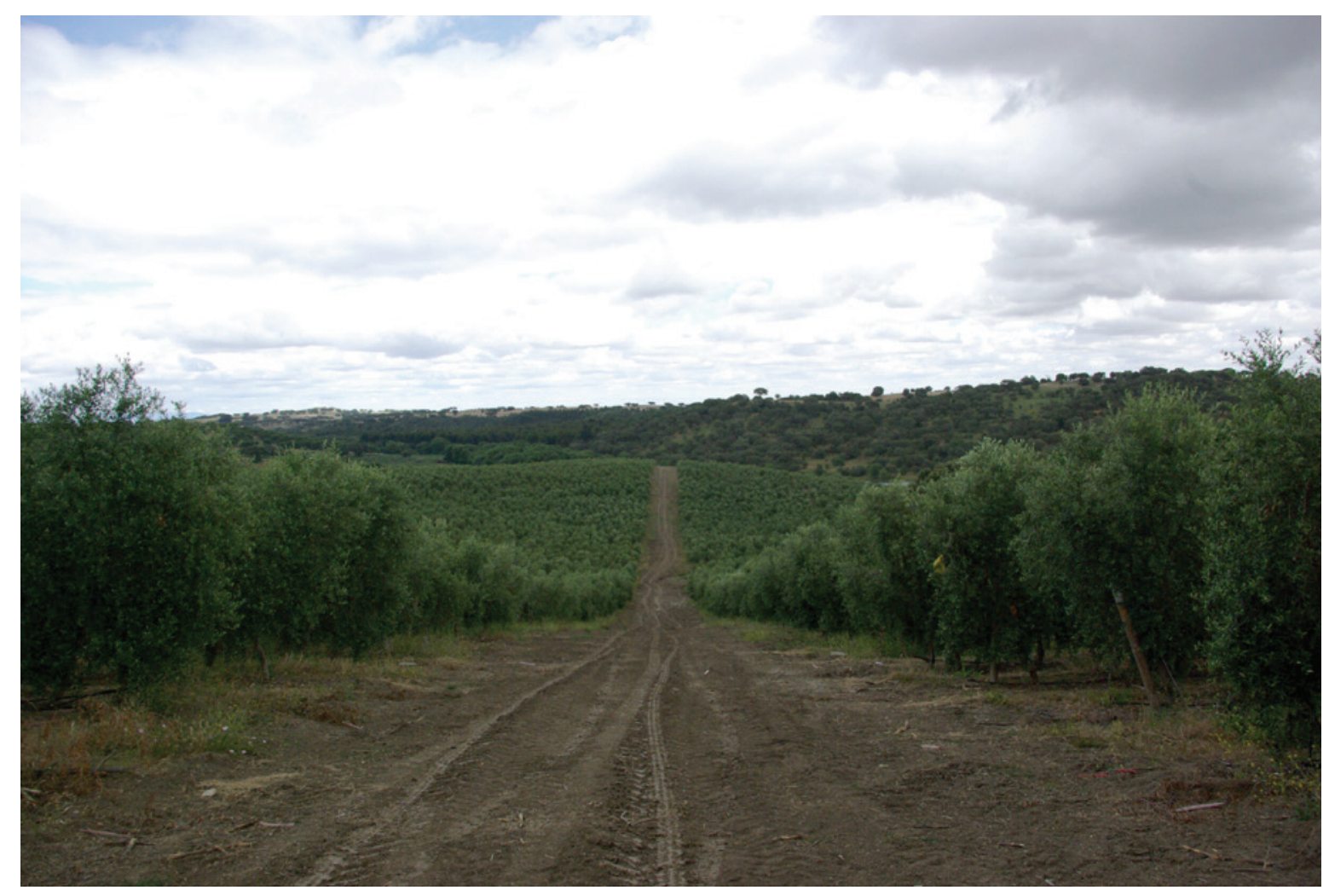

Figura 9 - Vista geral sobre sítio de período romano (Terrujo 1) afectado por olival intensivo.

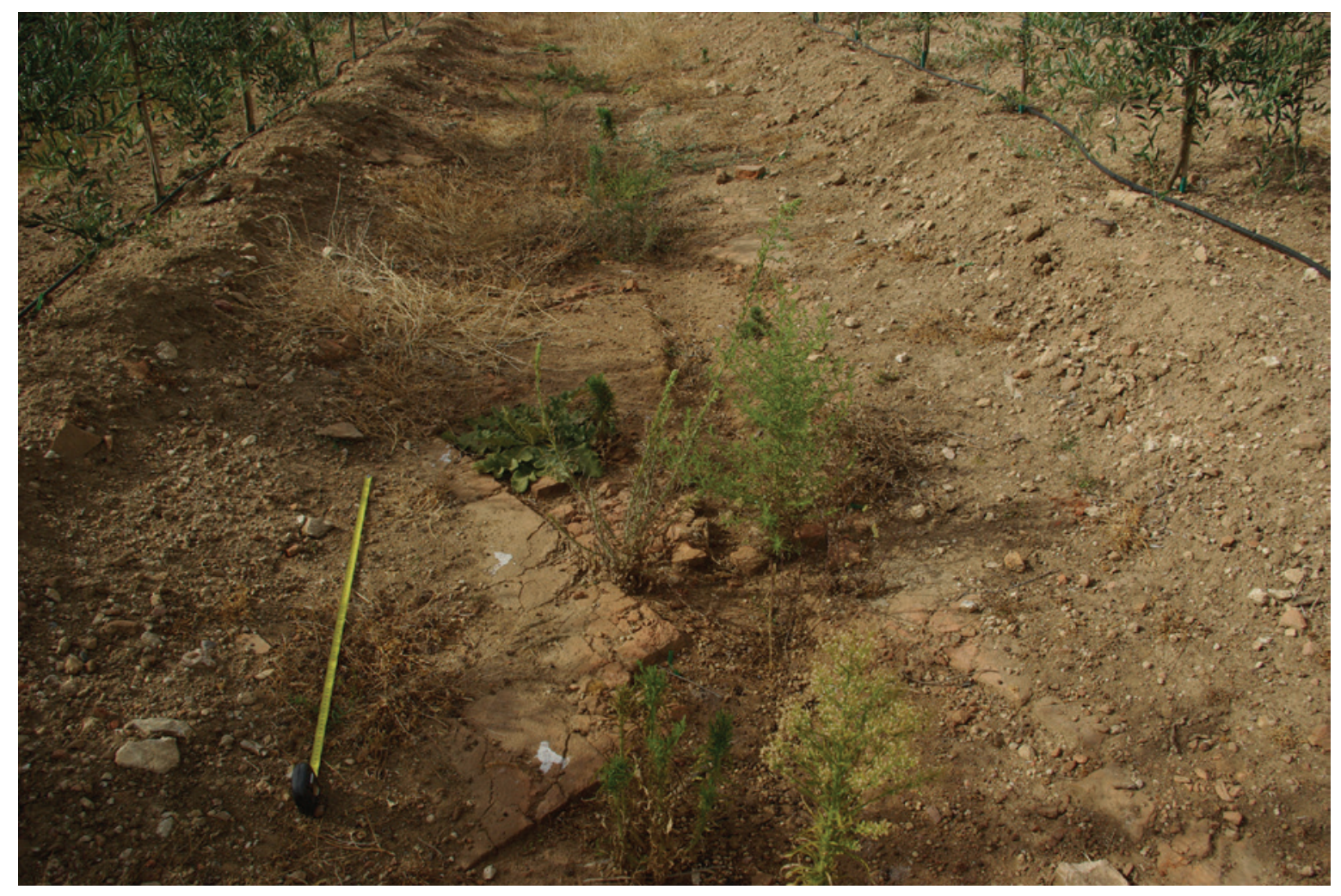

Figura 1o - Afectação de estruturas na villa Entre Águas I na sequência da plantação de olival intensivo. 



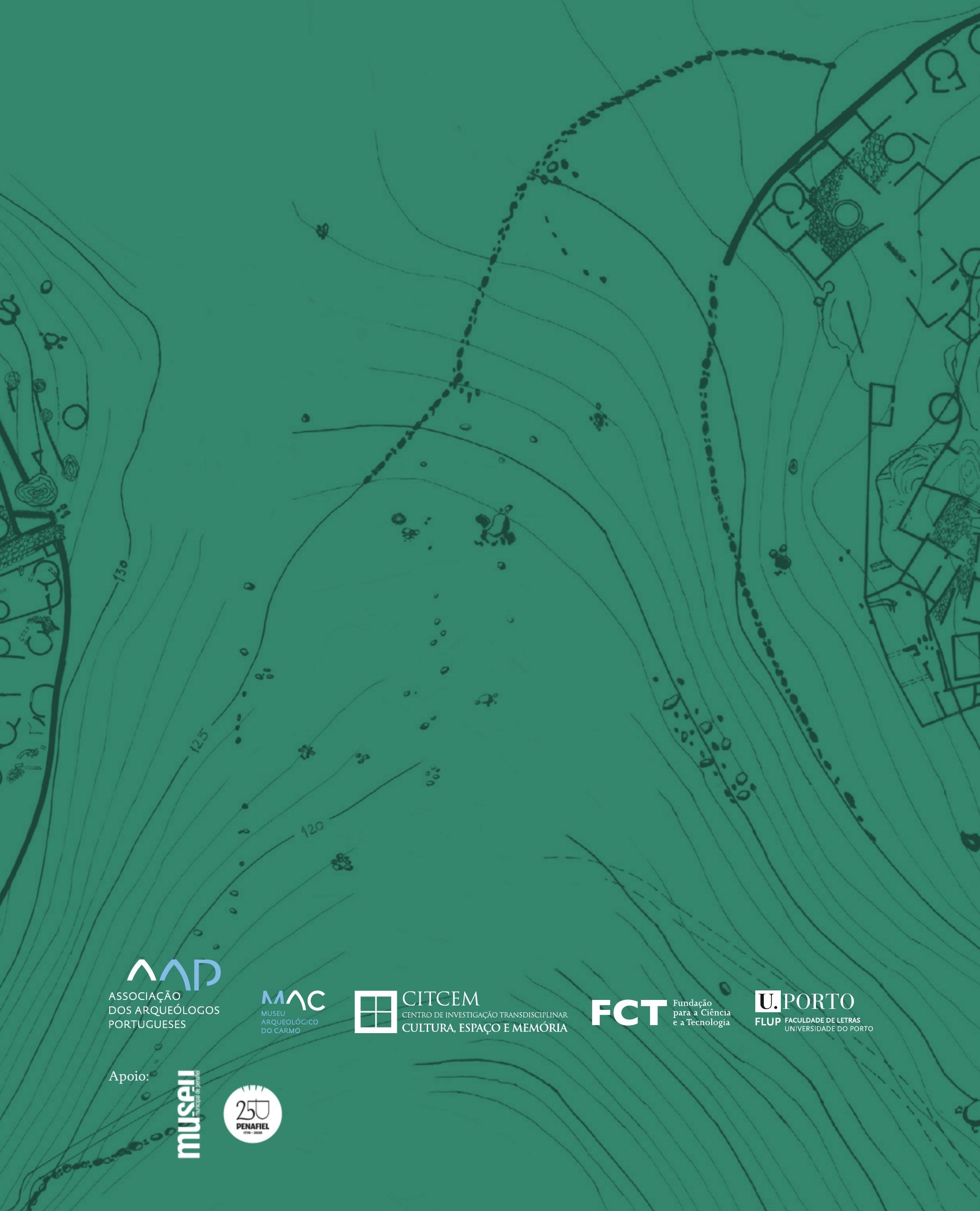

